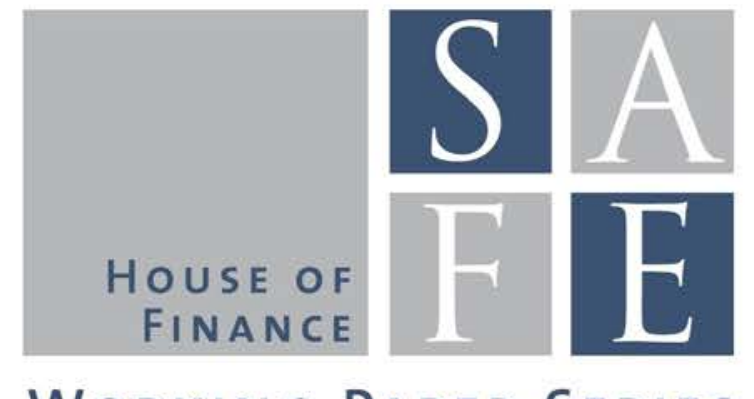

WORKING PAPER SERIES

Anderson Grajales-Olarte - Burak R. Uras - Nathanael Vellekoop

\title{
Rigid Wages and Contracts: Time- versus State-Dependent Wages in the Netherlands
}

SAFE Working Paper No. 258

SAFE I Sustainable Architecture for Finance in Europe A cooperation of the Center for Financial Studies and Goethe University Frankfurt 


\title{
Rigid Wages and Contracts: Time- versus State-Dependent Wages in the Netherlands
}

\author{
Anderson Grajales-Olarte* \\ Tilburg University, CentER and Bank of the Republic - Colombia \\ Burak R. Uras ${ }^{\dagger}$ \\ Nathanael Vellekoop ${ }^{\ddagger}$ \\ Tilburg University and CentER \\ University of Toronto and SAFE
}

September 2019

\begin{abstract}
We study nominal wage rigidity in the Netherlands using administrative data, which has three key features: (1) high-frequency (monthly), (2) high-quality (administrative records), and (3) high coverage (the universe of workers and the universe of firms). We find wage rigidity patterns in the data that are similar to wage behavior documented for other European countries. In particular we find that the hazard function has two spikes, one at 12 months and another one at 24 months and wage changes have time and state dependency components. As a novel and important piece of evidence we also uncover substantial heterogeneity in the frequency of wage changes due to explicit terms of the labor contract. In particular, contracts featuring flexible hours, such as on-call contracts, exhibit a higher probability of a change in the contract wage compared to fixedhour contracts. Once we split the sample based on contract characteristics, we also find that the response of wage changes to the time and state component is heterogeneous across different type of contracts - with relatively more downward adjustments in flexible-hour contract wages in response to aggregate unemployment.
\end{abstract}

Keywords: Wage rigidity, microdata, time dependency, state dependency, flexible-hour contracts.

JEL Classification Numbers: E24, J31.

The views expressed in this document are those of the authors and do not necessarily reflect those of the Central Bank of Colombia or those of its Board of Directors. We gratefully acknowledge research support from the Research Center SAFE, funded by the State of Hessen initiative for research LOEWE. Results include our own calculations based on microdata made available by Statistics Netherlands.

*E-mail: agrajaol@banrep.gov.co, a.grajalesolarte@tilburguniversity.edu

${ }^{\dagger}$ E-mail: r.b.uras@uvt.nl

${ }^{\ddagger}$ E-mail: vellekoop@safe.uni-frankfurt.de 


\section{Introduction}

Macroeconomists widely accept nominal wage rigidity as an imperfection that may generate substantial fluctuations in unemployment and output in the short term. The existence of nominal wage rigidity also provides a motivation for monetary policy to steer macroeconomic activity. Therefore, traditional Keynesianism and, more recently, the New Keynesian literature, emphasize the importance of identifying the degree of nominal wage rigidity in an economy. In this sense, a better understanding of patterns of wage rigidity is essential for uncovering the sources of business cycles and developing optimal policy instruments to handle economic fluctuations.

In this paper, we use a large, high-frequency micro-panel dataset on monthly salaries for all employees in the Netherlands to explore the dynamics of nominal wage rigidity. Our research objectives are threefold: (i) We estimate nominal wage rigidity at the worker level and (ii) investigate the wage changes of the employees that are related to the explicit contractual terms. The study of the relationship between wage flexibility and contractual-terms is very timely from both empirical and policy perspectives, especially in the context of advanced societies: both flexible-hour and part-time contracting has been rising over the last decade for many countries - a development concerning workers, employers as well as policy-makers. As figures 1 and 2 show, this trend is particularly clear in the Netherlands. ${ }^{1}$

\footnotetext{
${ }^{1}$ Several studies have investigated the reasons and possible causes of this trend in the Netherlands (e.g. Bolhaar, Brouwers and Scheer (2016) and de Beer and Verhulp (2017)). As mentioned by de Beer (2016), it is traditionally considered that economic and technological factors explain the increase in the participation of flexible labor contracts in recent years. On the one hand, because more flexible contracts help firms to absorb the economic fluctuations and the greater volatility of demand observed after the financial crisis. On the other hand, the prevalence of flexible contracts would be the consequence of changes in the labor skills demanded as a result of technological progress. Additionally, and from the point of view of the supply, some argue that modern workers prefer flexible contracts because they weigh more the autonomy that this contract provides against the stability and security provided by more permanent contracts.

de Beer (2016) and Euwals, de Graaf-Zijl and van Vuuren (2016) consider, however, that the mentioned causes are of second order of importance and claim instead that one of the main reasons to the rise of flexible contracts, on-call contracts specifically, is the lack of regulation for this type of contracts. This lack of an institutional framework reduces the costs and risks for employers, compared to more permanent contracts, in an environment of volatile markets.

van der Aa, van Buren and Viertelhauzen (2015) surveyed Dutch employers regarding their reasons for using flexible contracts. The authors partially confirmed the findings of Beer (2016) finding that employers prefer flexible contracts, among other reasons, depending on the nature of the work (flexible contracts for monotonous jobs and permanent contracts for specialists), due to their lower costs and because they perceive that flexible contracts are associated with lower risks related to labor laws.
} 
[Figure 1 about here.]

[Figure 2 about here.]

Research that uses microeconomic data to estimate the degree of nominal wage rigidity has concentrated mainly on uncovering the presence of downward wage rigidities, specifically, in the frequency of wage freezes. Some examples of this line of research are Mclaughlin (1994), Kahn (1997), Altonji and Devereux (2000), Gottschalk (2005), Fehr and Goette (2005), Dickens et al. (2007) and Deelen and Verbeek (2015). A few studies such as Bihan, Montornès and Heckel (2012), Barattieri, Basu and Gottschalk (2014), Kurmann and Mcentarfer (2017) and Ehrlich and Montes (2017), which use highly disaggregated data, also investigate the interaction between the frequency of nominal wage adjustments and delayed wage adjustments over the business cycle.

In this paper, we expand the existing literature on staggered nominal wage adjustments and fill an important gap by providing a detailed analysis of contract-level channels that are likely to explain empirically observed nominal wage stickiness in micro-data. Specifically, using a micro-detailed approach we aim to understand which particular characteristics of employee-employer contracts induce nominal wages to remain rigid during economic downturns.

A recent study that is closely related to our research is Sigurdsson and Sigurdardottir (2016), whose analysis with administrative data from Iceland reveals the presence of time and state dependency components in the setting of nominal wages. The authors' study shows that in Iceland downward rigidities of nominal wages are present to a large extent, and that wages tend to contract in response to recessionary trends, which indicates the relevance of statedependent wage setting. The Icelandic administrative data, however, to some extent restrict the conclusions reached by the authors on the deeper determinants of state-dependent salaries, since they can only contrast the behavior of nominal wages across industries, occupations and size of the firms. In this current study, we use administrative data from the Netherlands, which given its structure, allows us to make detailed comparisons between different employment contracts, in addition to occupations, firms and industry characteristics. The ability to make such comparisons also provides us with a framework to investigate the determinants of state dependence versus time dependence on wage determination. 
Several theoretical foundations have been highlighted in the literature that could explain why firms may hesitate to cut wages during economic downturns. Campbell and Kamlani (1997) provides a review of the theoretical literature and conducts a firm-level survey to isolate the different theories of wage rigidity qualitatively. However, the absence of observational data in the analysis of Campbell and Kamlani (1997) limits the applicability of their conclusions. Some promising theories for understanding wage rigidity are contract theory, the theory of implicit contracts, theories of efficiency wages, the theory of fair wages and the theory of insider-outside information. The contracts approach to wage rigidities, as proposed by Fischer (1977) and Taylor (1980), suggests that long-term employee-firm agreements require that wages be fixed in advance, which prevents wage negotiations from taking place on a regular basis. Advocates of implicit contract theory, such as Azariadis (1975) and Stiglitz (1984), argue that workers' risk aversion would induce them to prefer stable wages during the business cycle to wages that increase during expansions and decline during recessions. Therefore, risk aversion would give incentives to firms and workers to come to an implicit understanding of keeping wages stable during the business cycle. The implicit theory of contracts would imply that, wherever wages are rigid, firms are expected to pay relatively lower wages by avoiding to compensate for risk premia.

Our empirical analysis uses Dutch data at the employee level that cover from 2006 to 2012 (84 months). Our results show that the frequency of nominal wage adjustments in the Netherlands coincides with the general wage rigidity patterns documented recently for other European countries using high frequency data on wages such as for France (Bihan, Montornès and Heckel (2012)), Luxembourg (Lünnemann and Wintr (2009)) and Iceland (Sigurdsson and Sigurdardottir (2016)).

We divide our empirical analysis into two parts. In the first part we provide a description of the nominal wage stickiness of the Dutch economy. In this preliminary phase we find that nominal wages are downward rigid across a wide range of industrial clusters. We also document a clear seasonal pattern in the degree of rigidity. Likewise, we document significant heterogeneity in nominal wage rigidity across industries and occupations, as well as with respect to firm-size. Importantly, the duration analysis of a change in the contract wage confirms earlier findings in the literature regarding the shape of the 
hazard function. Accordingly, we find that the hazard has two spikes, one at 12 months and another one at 24 months.

As a highlighted novel contribution of our research from this first part, we find empirical evidence that the contractual terms of employees are important to understand the degree of nominal wage rigidity. To this end, we uncover that flexibility of contractual hours significantly correlates with the likelihood of (downward and upward) nominal wage adjustments, i.e. flexible-hour contracts dominate fixed-hour contracts in terms of wage flexibility. Specifically, on average, the period during which the nominal wage in contracts with fixedhours remains unchanged is $61 \%$ longer than in contracts with flexible-hours. Interestingly, we do not find any significant difference in nominal wage stickiness when we slice the space of contracts in terms of contractual hours (parttime vs. full-time) and tenure (fixed-term vs. permanent). These findings not only help to understand the determinants of aggregate nominal wage rigidity, but are also increasingly relevant given the change in composition observed in the participation of different types of contract and employment policies during the period of analysis.

In the second part of the paper, using a formal econometric exercise, we study time-dependence and state-dependence in the determination of nominal wages in the Netherlands. We find that time- and state-dependency, represented by changes in macroeconomic variables (such as inflation and unemployment), affect the probability of observing both increases and nominal wage reductions. Time- and state-dependency affect the probability of observing changes in nominal wages for the pooled sample, that is, without disaggregation by type of contract, but also when considering the different types of contracts separately. We also find that the effect of time- and state-dependency is not homogeneous across different contracts. For example, with respect to wage reductions (i.e. downward rigidities), which the past literature primarily concentrated upon, we find that flexible-hour contract wages are more likely to decrease in response to rising unemployment. No other type of employment contracts (including part-time and fixed-term employment status) exhibits this empirical pattern - yielding another unique and important empirical feature associated with flexible-hour contracts.

The rest of this paper is organized as follows. Section 2 presents a summary of the theories of wage rigidity while Section 3 summarizes the institutional setting for wage determination in the Netherlands. Section 4 describes in detail 
the data we use. Sections 5 and 6 present our empirical results. Section 7 concludes.

\section{Theories of Wage Rigidity: Time-Dependent vs. State- Dependent Wage Setting}

There are two broad classes of theories that aim to describe the behavior of wage adjustments: time-dependent and state-dependent models of wage determination. According to time-dependent models of wage adjustments, the state of the economy does not play any role in determining the likelihood and the size of a wage change. Earlier examples of time-dependent wage setting include Fischer (1977) and Taylor (1980), who propose that wages remain constant for an exogenous and deterministic number of periods, such as a particular number of months or a year. Fisher-Taylor type of time-dependent wage setting can be motivated by the behavior of wages observed among unionized workers. Also, in this family of models, a feature pioneered in Calvo's famous 1983 article suggests a random duration in nominal adjustments. ${ }^{2}$ Building upon this feature, many New-Keynesian macro models, such as Smets and Wouters (2003), assume that wages change at random with a probability to reoptimize wages that remains constant over time. Although Calvo type wage stickiness is hard to support with an empirically justifiable microfoundation, the tractability that it induces makes Calvo-stickness a desirable assumption to apply in New-Keynesian models.

Models with state-dependent wage setting build upon the theoretical argument that fixed costs to renegotiate employment contracts prevent frequent adjustments in wages. Assumptions proposed by Caplin and Spulber (1987) and Fehr and Goette (2005) argue that fixed cost of wage adjustments imply that the likelihood and the size of wage changes vary over time with the conditions of the macroeconomy, the industry and the firm.

In this paper we aim to disentangle the presence of time-vs-state dependent wage setting using a rich data-set for the case of the Netherlands.

\footnotetext{
${ }^{2}$ Although Calvo (1983) develops a model of sticky-prices, many papers in the literature implemented Calvo stickiness also for the case of wages.
} 


\section{Institutional Setting}

The Netherlands is a small, open economy and part of the eurozone for the years of our study. With a population of 16.9 million inhabitants in 2015, it is more populous than the state of Illinois, but smaller than the state of New York.

In 2015 there were about 8.29 million people in the labor force, with 6.9 million workers and 1.38 million self-employed. The three largest industries in terms of workers are health care (16\%), trade (15\%), and manufacturing (10\%).

Important for our analysis is the distinction between workers with a contract of indefinite length (74\% as of 2015) and a fixed-term contract (26\%). As Table 1 shows, the group of fixed-term contracts is quite heterogeneous: $31 \%$ of the workers with a fixed-term contract are on-call; $19 \%$ have no hours defined, and $14 \%$ work for temporary work agencies (Dutch Labor Force Survey Statistics for 2015). Of the remaining workers with fixed-term contracts, $10 \%$ of the workers have a temporary contract for less than a year, and $11 \%$ have a temporary contract longer than a year.

[Table 1 about here.]

Legally there are no limits on the length of time of the first fixed-term contract an employer offers, but there are regulations for the maximum number of successive contracts the employer can offer before a fixed-term contract alters into a contract of indefinite length (OECD EPL database, 2013). After three successive fixed-term contracts and/or a period of 36 months covered (including prolongations), the fourth (or next) contract is automatically of indefinite length. Exceptions to this rule are possible in collective bargaining agreements. In practice, the difference between temporary contracts and contracts of indefinite duration is the degree of employment protection. Termination of a labor contract by the employer involves either the courts or the public employment service (OECD EPL database, 2013), with an equal distribution of cases between the two. The courts are more expensive in terms of severance pay but are typically shorter and less administratively burdensome for the employer. Severance pay depends on the tenure of employment, gross wages and some discretionary factor applied by the courts. The average OECD score for job protection of workers with a regular contract is 2.04 in 2013 (on a scale from 0 , no protection, to 6 , maximum job protection). Workers with regular contracts in the Netherlands are better protected (score of 2.82) compared to the OECD. 
The opposite is true for workers with a temporary contract: the OECD average is 1.72, whereas the score for Dutch workers with a temporary contract is 0.94 .

With respect to hours worked, the Dutch labor market can be characterized by a high degree of labor flexibility. In 2015 almost half of all workers worked less than the standard number of hours: $26.3 \%$ of the men and $75.1 \%$ of the women. The share of involuntary part-time work is very low: $8.6 \%$ of part-time workers work less than fulltime involuntarily (OECD, 2015). Overtime hours are measured in our data to the extent that hours are paid at a higher wage rate, e.g. weekend and night shifts in certain industries. Overtime premiums and overtime hours regulation are typically covered in collective bargaining agreements.

Trade union density, defined as the number of union members over the number of wage and salary earners, is with $17.8 \%$ comparable to the OECD average of $17.0 \%$ (OECD, 2013). For comparison with some of the mentioned studies, trade union density is lower in France (7.7\%) and the United States (10.7\%), and higher in Luxembourg (32.8\%) and Iceland (82.4\%). Union membership is low, but coverage of wage bargaining is relatively large. Four bargaining regimes can be distinguished (Hartog, Leuven and Teulings (2002)): company level bargaining, industry level bargaining, mandatory extension of an industry agreement, and no collective bargaining.

Figure 17 in the appendix shows the behavior of GDP growth, CPI inflation and unemployment in the Netherlands in the period 2006-2012.

\section{Data}

One reason empirical research on wage rigidity is limited - especially to the end of identifying the models and theoretical channels that drive the degree of wage rigidity - is the lack of high-frequency microdata, which provide detailed information on contracts between employees and employers. In this respect, there are two fronts of the state of the art datasets that are required to conduct this research project. On the one hand, to capture potential rigidities in wage adjustments over the business cycle frequency, the data should be at a monthly (or at the least of quarterly) frequency. On the other hand, the details of employment contracts should provide enough information about the duration of the agreement and other features of the employee-employer rela- 
tionship to allow for a thorough investigation of the sources of wage rigidity that we are interested in.

The analysis in this paper is based on anonymized non-public census-data from Statistics Netherlands (CBS) for the period of 2006-2012. In particular, the dataset allows us to use information on firms from the General Business Register (ABR), personal characteristics of individuals affiliated with municipal administration registers (GBA) and monthly quantitative and qualitative data regarding jobs and wages of employees in Dutch companies (POLISBUS). ${ }^{3}$ Firms collect the monthly wage data and report it to the unemployment insurance agency. All legal workers are covered by unemployment insurance, and unemployment insurance is based on the number of years of work at all firms (including gaps), and the wages earned in the 12 months prior to unemployment, as well as hours worked. The fact that firms report the data minimizes the measurement error in wages and hours reported. Moreover, we observe in our data the universe of firms, both public and private.

In the first quarter of 2007, the census comprises around 980,000 firms with approximately 8,05 million workers among 480 industries (5-digit NACE), from which, due to computational constraints, we take a $5 \%$ random sample stratified by sector and firm size. The data includes monthly contract wages, variable compensation, payroll taxes and hours worked. At the level of the firm 5digit industry code, collective labor agreement code (if any), and firm balance sheets and income statements can be linked to workers at incorporated firms. The observational unit is defined as the relationship between an employee and the employee's job at a firm (i.e., wage trajectory) which can be followed for up to seven years in our sample. The use of the wage trajectory as our observation unit means that the wage changes discussed in this paper are within job wage changes. As standard in the literature, our measurement unit is hourly wages, where wages are given by the contract wage.

Measuring the nominal rigidity in wages is challenging for two reasons: low frequency (annual) data and measurement error in wages, hours or both. The dataset we use in our research helps us with both issues. First, the employeelevel dataset is at a monthly frequency giving us the opportunity to observe the exact month of a wage change within a given wage trajectory. We also observe the exact month of a new wage trajectory, as well as the month of a job exit

\footnotetext{
${ }^{3}$ Under certain conditions, these microdata are accessible for statistical and scientific research. For further information please contact Statistics Netherlands at microdata@cbs.nl.
} 
and entry. Moreover, we can decompose total monthly compensation into the contract wage and variable compensation. These are important improvements on existing research. Most available microeconomic datasets on wages are at an annual frequency making the estimation of short-run wage rigidities quite imprecise. Only few studies provide evidence on wage rigidities at a quarterly frequency, such as Bihan, Montornès and Heckel (2012) for France, and Barattieri, Basu and Gottschalk (2014) for the United States; or at the monthly frequency: Lünnemann and Wintr (2009) for Luxembourg, and Sigurdsson and Sigurdardottir (2016) for Iceland. To the end of contractual details, our data differentiates between variable and base compensation of employees, provides information on hours worked, and the type of contracts (fixed-term versus permanent). The second challenge is measurement error. Gottschalk (2005) finds that measurement error in surveys can be substantial, due to imperfect recall or unwillingness to report hours worked or wages received (or both).

Our research isolates the effects of explicit contractual terms on estimated wage rigidities from that of factors due to firm, industry and macroeconomic characteristics. Moreover, we observe all employees at each firm, which allows us to identify each firm-worker pair in the data uniquely. An additional novel feature of our data is that we observe start and end of unemployment spells and can precisely infer wage changes of job-finders.

Our empirical methodology to estimate wage rigidity follows the recent literature (e.g., Gottschalk (2005); Bihan, Montornès and Heckel (2012); Barattieri, Basu and Gottschalk (2014)) and Sigurdsson and Sigurdardottir (2016).

Data Treatment. Even though we are dealing with high-quality administrative data, some observations should be excluded because it is likely that they contain measurement errors or are the result of misreporting. Specifically, we leave out any observations with nonsense values (e.g. negative nominal wages or number hours worked) and to trim possible outliers, we drop the first and/or the last percentile in most of the variables.

The data cleaning process, however, does not entirely eliminate the presence of measurement error, or misreporting, which may obscure our estimation of the level of wage rigidity. Specifically, we could potentially find spurious changes in wages that are the product of misreporting or due to rounding. In order to differentiate actual wage changes from the spurious ones, and reduce the bias generated by the latter, we implement an identification strategy that is standard in the literature. In general terms, the identification strategy assumes 
that a step function can describe wage changes. That is, we assume (as intuition dictates) that individual wages stay constant for some unknown number of months and then, when they change, they change in a discrete manner. One way to implement this identification strategy is using a structural break test. However, this econometric approach used by Gottschalk (2005) is computationally expensive and becomes infeasible when the number of wage trajectories is big, as in our case. ${ }^{4}$ Instead, we implement the identification strategy using a heuristic approach which can be summarized as follows: ${ }^{5}$

1. We eliminate the last observation of a wage trajectory if this includes a wage change. This allows us to take into account any possible payment received by the employee at the end of the labor relationship, such as severance payments. Symmetrically, we eliminate the first observation of a wage trajectory if it is followed by an immediate change in wage as well. This way we take into account any possible "extra" payments that wage earner receives in the first month of the employment relationship, e.g. sign-on bonuses.

2. We drop wage trajectories that last for less than 3-months. The idea behind this is to avoid the possible bias generated by very short and potentially volatile wage trajectories.

3. We eliminate wage trajectories where the number of wage changes is greater than $80 \%$ of the total possible number of changes (e.g., a wage trajectory of 12 months with ten wage changes is dropped from our analysis). This is in line with our overall identification strategy: wages stay constant for some unknown period.

4. We correct wage trajectories that contain V-shape or inverted V-shape wage changes, i.e. a wage reduction followed immediately by an increase (or vice versa). This kind of sharp wage reversals are potentially due to misreporting or due to rounding error. In our analysis, we take such sharp wage-reversals as a "no-change" in wage.

5. Finally, we correct wage trajectories that contain wage reversals in a time span of three months, i.e. a wage change that is reverted after two or three

\footnotetext{
${ }^{4}$ See Barattieri, Basu and Gottschalk (2014) for an application.

${ }^{5} \mathrm{~A}$ similar approach is used in Sigurdsson and Sigurdardottir (2016) and Lünnemann and Wintr (2009).
} 
months leaving the wage exactly as before the change. We consider those wage-reversals as a "no-change" in wage. ${ }^{6}$

Figure 3 depicts the implementation of the above algorithm for a fictional individual over a 24-month wage trajectory. ${ }^{7}$

[Figure 3 about here.]

\section{Wage Rigidity: Descriptive Analysis}

In this section we conduct a duration analysis and a multinomial logit estimation to document the patterns of employee-level wage adjustments in the Netherlands. We split our results in two. At first, we present a set of findings, some of which have also been highlighted in the previous literature for other European countries and the US. We then show and discuss another set of findings that are novel for the literature - regarding labor contract types and wage rigidities.

The baseline results - that we present in Tables 2-7 and Figures 6-11 - reveal the presence of rigid wages, and in particular downward wage rigidities throughout sectors, firm-size groups and employment types. This means when we compare wage "decreases" against "increases", contractions in wages are significantly less common than rising wages. These results are in line with those found in the literature as we will delineate below.

Table 2 shows that in the aggregate we capture a frequency of "no-change in wages" of $84.9 \%$. This degree of wage rigidity is comparable to the findings of Sigurdsson and Sigurdardottir (2016), who document 87\% probability of "no change in wages" for the case of Iceland, and Lünnemann and Wintr (2009), who document $85.7 \%$ - 93\% probability of "no change in wages" for the case of Luxemburg. Both of these studies - like in our approach - use monthly data. Using quarterly data Bihan, Montornès and Heckel (2012) find a wage rigidity of $62 \%$ in France and Barattieri, Basu and Gottschalk (2014) uncover a wage rigidity of $78.4 \%-83.7 \%$ in the US. The quarterly equivalent of our wage rigidity

\footnotetext{
${ }^{6}$ Table 17 in the appendix shows the number of observations lost in each step of the cleaning process.

${ }^{7}$ The wage trajectory in this figure does not correspond to the wage trajectory of any individual in our sample nor in the population. The numbers were fabricated for illustrative purposes.
} 
is $62.1 \%$ of no-change, which coincides with the degree of rigidity documented in France by Bihan, Montornès and Heckel (2012). ${ }^{8}$

[Table 2 about here.]

Figure 4 shows the estimated conditional hazard probability of a wage change based on the raw data. This figure indicates that wages are more likely to change every 12 months, and to a lesser extent if the wage remains unchanged for two years. More importantly, the high probability of observing a wage change every period depicted in Figure 4 reveals the presence of some measurement error in the raw data.

[Figure 4 about here.]

Figure 5 presents the hazard function of a wage change based on the data obtained after the cleaning procedure explained in detail in Section 4. The highest probability of a wage change is observed after 12 months: an employee who had an unchanged wage for 11 months has about a $50 \%$ chance of observing a change in his wage in the 12th month.

Similarly, if the wage remained unchanged for 23 months, the worker has a probability close to $20 \%$ of observing a wage change in month 24 . A similar hazard function - with peaks in 12th and 24th months - was also documented by Gottschalk (2005) and Barattieri, Basu and Gottschalk (2014) for the case of the United States.

\section{[Figure 5 about here.]}

Moreover, Figure 6 and Table 3 reveal a clear seasonality (synchronization) in wage changes. We find that wages are more likely to rise in January and July. Sigurdsson and Sigurdardottir (2016) found a similar pattern in Iceland but the peaks in their work are documented to be in January and June. Similarly, using the administrative data from Luxemburg Lünnemann and Wintr (2009) uncovered a peak in January. Bihan, Montornès and Heckel (2012) also showed a synchronization in wage changes for the case of France. Finally, for the US Barattieri, Basu and Gottschalk (2014) showed weak evidence of synchronization. Additionally, our data also points out that there is evidence of staggered

\footnotetext{
${ }^{8}$ Table 14 in the Appendix shows the heterogeneity in the nominal wage rigidity according to some characteristics of the employees such as the type of marriage relationship and gender.
} 
wages at the aggregate level. Figure 6 and Table 3 show that most of the wage changes are distributed over the course of the year. ${ }^{9}$

[Figure 6 about here.]

[Table 3 about here.]

[Table 4 about here.]

Figure 7 and Table 4 (in the Appendix) show that wages in the Netherlands have become more rigid after the financial crisis. Sigurdsson and Sigurdardottir (2016) found a similar pattern regarding the increase of wage rigidity after the crisis for the case of Iceland. However, it is important to note that the "economic recovery" had not been observed yet in the data that they use, because the last period for the analysis is 2010 in Sigurdsson and Sigurdardottir (2016). ${ }^{10}$

\section{[Figure 7 about here.]}

The results we obtain to the end of variations in marital status and gender of the employee and their implications for wage rigidities are in line with the findings of the previous literature as well. With respect to the marital status the rigidities are comparable between married and non-married, while married workers tend to exhibit rigidities to a larger extent (as also evidenced in Lünnemann and Wintr (2009)). Similarly, results are very close between male and female employees, but male workers appear to have more rigid wage profiles compared to female (also as in Lünnemann and Wintr (2009)).

As a novel piece of evidence Figure 8 and Table 5 uncover a clear positive correlation between age and wage rigidity. ${ }^{11}$ For instance, the probability of a no-change in wages grows monotonically with the age of the employee until they reach 73 years (for employees over 73 years of age, the probability of a non-change decreases slightly). Therefore, while for employees between 63 and 73 years the likelihood of a no-change in wages is $88.1 \%$, this likelihood is $77.7 \%$ for employees under 23 years of age. We observe a monotonic negative

\footnotetext{
${ }^{9}$ For France, Bihan, Montornès and Heckel (2012) found a stronger evidence of staggering (the probability of a wage increase is greater than $20 \%$ in every quarter).

${ }^{10}$ However, it is too early to talk about a sustained recovery since the Netherlands registered a negative GDP growth in the last year of our analysis.

${ }^{11}$ Lünnemann and Wintr (2009) discuss the association between age and wage rigidity as well, but in their case age cannot be separated from marital status.
} 
relationship between the age of the employee and the probability of a wage increase. As Table 5 shows young workers are twice as likely to experience a wage increase compared to their older counterparts. The negative link between the age of the employee and the likelihood of a wage reduction shows less variance than for the cases of no-change and wage increases.

[Figure 8 about here.]

[Table 5 about here.]

The implication of the estimated correlation between wage rigidity and workers' age gains additional relevance once we observe the behavior of the age groups during the observation period. Figure 9 shows this evolution between 2006 and 2012. We can see that, in general, the age groups with less rigidity in wages, ages between 23 and 53 years, have decreased their participation in the working population. In contrast, employees over 53 have shown a steady increase in their share.

[Figure 9 about here.]

Finally, we also document the heterogeneity of wage rigidities with respect to firms' size and industry classifications. First, Figure 10 and Table 6 illustrate that wages become more flexible with the size of the company, which was also highlighted in the past literature. ${ }^{12}$ Also, as documented in the past literature, we show that the probability of observing a wage increase is positively related to firm size. ${ }^{13}$ We also find a negative relationship between firm size and the probability of a wage-contraction - as in Bihan, Montornès and Heckel (2012), which differs from the findings of Sigurdsson and Sigurdardottir (2016) and Lünnemann and Wintr (2009), who show that the probability of observing a wage decrease is essentially independent of firm size. Second, sectoral comparisons reveal that for workers at municipalities, schools and subsidized sectors wages are more downward rigid compared to the private sector, as illustrated in Table 7 (Figure 11). Further decomposition of the sectors in industries shows that, for instance, wages in the Telecommunication industry are

\footnotetext{
${ }^{12}$ Sigurdsson and Sigurdardottir (2016) and Lünnemann and Wintr (2009) find a similar empirical pattern, while Bihan, Montornès and Heckel (2012) find an inverted U-shaped - with more wage rigidity for the case of mid-size firms.

${ }^{13}$ The same pattern is observed by Sigurdsson and Sigurdardottir (2016), Lünnemann and Wintr (2009) and Bihan, Montornès and Heckel (2012)
} 
the least-rigid whereas the wages of the Banking industry are most rigid - with a substantial amount of heterogeneity in the rigidity of wages across the spectrum of industries. ${ }^{14}$

[Figure 10 about here.]

[Table 6 about here.]

[Figure 11 about here.]

[Table 7 about here.]

Labor Contracts and Wage Rigidity. Employment contract details in our administrative data provide us with a novel source of variation at the employee level and allows to explore a set of empirical regularities, which the previous literature did not concentrate on. As we highlight in Table 2 we observe that employees with a flexible hours employment relationship have substantially lower degrees of wage rigidity - when it comes to both downward and upward adjustments in wages - compared to employees with fixed hours employment relationships. ${ }^{15}$ The frequency of no change is $76.1 \%$ for the case of flexible hours contracts, while it is $\mathbf{8 5 . 2 \%}$ for fixed hours contracts. This is an economically significant difference with respect to hourly-wage flexibility of flexiblehour contracts. We would like to note that in the Netherlands, the participation of employees with flexible contracts has increased considerably during the period of analysis (Figure 12).

In Figure 15 and Table 9 we break down flexible-and fixed-hour contract types into sub-components and present a clear positive correlation between "labor flexibility" and "wage flexibility". Specifically, wages of more flexible types of labor, such as temporary \& on-call workers, is a lot less rigid compared to regular workers and directors. While the likelihood of no change in wages is $91.4 \%$ for directors, it is $73.9 \%$ for temporary workers. This difference is driven by differences in both downward and upward adjustments in wages. This observation is very relevant from a macro point of view because there has been an increase in the number of flexible labor positions in The Netherlands over the recent years. As Figure 16 shows, for instance, the percentage of on-call

\footnotetext{
${ }^{14}$ Table 18 in the appendix shows a sectoral classification at a higher level of aggregation.

${ }^{15}$ Flexible employment relationships include temporary workers and on-call. Fixed relationships correspond to directors, interns, SWS-er and rest. Tables 15 and 16 in the appendix shows the distribution of the different type of contracts in our sample.
} 
workers in the Netherlands more than doubled between 2003 and 2015, going from $3.8 \%$ to $8 \%$, with respect to the total number of workers.

[Figure 12 about here.]

Our data also allows us to capture a difference in the degree of rigidity of wages when tenured and untenured contracts are compared against each other; however, the difference is far from the level that we observe for the comparison between flexible-hour and fixed-hour contracts. Having said this even small differences in the level of wage rigidity between these contracts can have important implications given how the participation of tenured and untenured contracts has evolved between 2006 and 2012. Figure 13 shows that the percentage of tenured contracts was relatively low in 2006, but it increased significantly in a period as short as six years (an increase of around ten percentage points). We observe the opposite behavior, but with the same magnitude, for untenured contracts.

[Figure 13 about here.]

Finally, we also unpack the contract details of employees and observe further interesting patterns in rigidities of wages across types \& terms of contracts. First, in Figure 14 and Table 8 we show that the degree of wage rigidity is higher for employees working for more hours. For instance, while the likelihood of a no-change for the group of $35+$ hours is $85.7 \%$, the same likelihood is $82.6 \%$ for employees working for less than 12 hours a week. The downward rigidity drives a large portion of this difference in wages. However, again in comparison to the dimension of "hour flexibility" splitting the sample based on the dimension of "hours worked" does not yield economically too significant differences between part-time and full-time employment contracts.

Having established a novel piece of evidence concerning the flexibility of wages associated with flexible-hour labor contracts, next we move on to study time-and state-dependent wage setting behavior across different types of labor contracts using a formal regression analysis.

[Figure 14 about here.]

[Table 8 about here.]

[Figure 15 about here.] 
[Table 9 about here.]

[Figure 16 about here.]

\section{Wage Rigidity: Time- and State-Dependency}

As we have covered in Section 2, the well-known theories of state and time dependency propose different underlying reasons for changes in wages. Theories of state-dependency suggest that the probability of adjustments in wages moves with the state of the economic environment. Theories of time-dependency, in turn, argue that this probability depends on the temporal context, given by a specific period of the year, or the duration of the wage spell - and it is independent of the economic conditions.

The database at our disposal, with the benefits associated with a high periodicity, high disaggregation and ample information at the level of the employee as we described in Section 4, presents a unique opportunity to test which theory best explains the dynamics of nominal wages in the Netherlands. With this objective, we estimate the following fixed-effect model for the probability of observing a change in nominal wages - separately for reductions in wages and wage increases,

$$
\begin{aligned}
& y_{i, t}=\alpha+\boldsymbol{q}_{i, t} \boldsymbol{\delta}+\boldsymbol{x}_{i, t} \boldsymbol{\beta}+\boldsymbol{z}_{i, t} \boldsymbol{\gamma}+v_{i}+\epsilon_{i, t}, \\
& y_{i, t}= \begin{cases}1 & \text { if } w_{i, t} \neq w_{i, t-1} \\
0 & \text { if } w_{i, t}=w_{i, t-1}\end{cases}
\end{aligned}
$$

where $i$ is the wage trajectory, $t$ is months and $w$ is the nominal hourly wage. ${ }^{16}$

Equation (1) contains variables aimed to capture time- and state-dependent components of wage changes. Specifically, vector $\boldsymbol{q}$ captures the potential of time-dependency by including monthly and duration dummies. Vector $\boldsymbol{x}$ proxies the possibility of state-dependency by incorporating factors related to the macroeconomic environment and firm productivity. In particular, $\boldsymbol{x}$ includes accumulated inflation $\left(\pi_{t-1}-\pi_{t-\tau_{-1}}\right)$, accumulated unemployment variation $\left(u_{t-1}-u_{t-\tau_{-1}}\right)$ and a proxy for accumulated firm productivity, which is given by the change in the size of the firm - measured in terms of number

\footnotetext{
${ }^{16} \mathrm{~A}$ wage trajectory is given by $y_{i} \equiv y_{e j f}$ with $e$ representing employee, $j$ employee's job and $f$ is business unit. $v_{i}$ represents wage trajectory fixed effects.
} 
of employees $\left(n e_{f, t-1}-n e_{f, t-\tau_{-1}}\right)$, with $\tau_{-1}$ being the duration of the wage spell. ${ }^{17}$ These variables measure the accumulated disequilibrium between the optimal wage set at the beginning of the spell and current wage (Cecchetti (1987)).

The vector $z$ comprises of characteristics of the wage trajectory and the business unit, which are employment policy, employment relationship, type of contract, type of relationship, contract hours, type of job, size of the business unit, and age of the employee.

\subsection{Results: Time- vs. State-dependency}

Table 10 shows regression results, using the entire sample, for the case of wage reductions, which tell us about the nature of downward wage rigidities in the data. Column A shows the estimated values for the model that does not include dummy variables of duration, while column B includes dummy variables of duration for up to 12 periods. $^{18}$

In Table 10 we find statistical significance of the seasonality variables and the duration dummies, both supporting the presence of time dependence. The Wald test rejects the hypothesis of no joint significance and the hypothesis of equality of the coefficients at $1 \%$. The seasonal pattern does not present peaks as clear as in the case of wage increases; wage reductions are more likely to occur in January, but this probability is not very different from those observed in other months. In addition, it is more likely to see a wage reduction after a short period without wage changes (four months or fewer). These last two results are comparable to those found by Sigurdsson and Sigurdardottir (2016).

[Table 10 about here.]

With respect to downward wage rigidity we also find evidence for statedependency which survives the incorporation of duration variables. ${ }^{19}$ How-

\footnotetext{
${ }^{17}$ Sigurdsson and Sigurdardottir (2016) and Bihan, Montornès and Heckel (2012) include these variables as well, but in the context of a Tobit type II model that allows them, in addition, to model the size of wage changes. We have opted for a linear model due to computational constraints associated with the size of our sample. However, we verified, using a considerably smaller sample, that our results are comparable with those obtained with a Probit model, in line with the specification in Sigurdsson and Sigurdardottir (2016) and Bihan, Montornès and Heckel (2012).

${ }^{18}$ The model includes the complete set of dummy duration variables. Due to space restrictions, we only show a subset of them.

${ }^{19}$ In contrast, Sigurdsson and Sigurdardottir (2016) found that the probability of a wage reduction does not respond to changes in current accumulated inflation or unemployment.
} 
ever, the effects of macroeconomic variables on the probability of wage reductions are of lesser magnitude. Specifically, Table 10 shows that on average (for models with and without dummy duration variables), an increase in accumulated inflation of $1 \mathrm{pp}$ increases the probability of a wage reduction by $0.65 \%$. Similarly, an increase in accumulated unemployment of $1 \mathrm{pp}$ decreases the probability of a wage reduction by $0.35 \% .{ }^{20}$

[Table 11 about here.]

Table 11 shows the results, using the entire sample, for the case of wage increases. The estimated results confirm the evidence of seasonality in wage changes mentioned in section 5. In this regard, a Wald test rejects the hypothesis that the coefficients associated with the monthly dummy variables are jointly not significant. The same test rejects the hypothesis that all the coefficients associated to the months are statistically equal and, instead, as shown in Table 11 wage increases are more likely to occur in January and July.

This pattern in the temporal behavior of wage increases represents evidence against Calvo's approach to determining wages (equal probability of observing a change in each period). The pattern seen in the estimate instead supports the notion of Taylor-type time dependence, in which wage changes occur at certain fixed time periods, and is in line with our findings in the analysis of the hazard function. The strong statistical significance of the dummy variables of duration, at $1 \%$ in almost all cases, reinforces the time-dependency component. It is worth noting that, unlike Sigurdsson and Sigurdardottir (2016), the dummy variables of duration maintain their effect on the probability of a wage increase even when the model takes the months into account as an independent variable.

In our analysis we also find substantial evidence for state dependence associated with wage increases. This empirical observation remains, although with a reduced magnitude in some cases, even after including duration dummies. In particular, as intuition suggests, we find a positive and statistically signifi-

\footnotetext{
${ }^{20}$ Regarding the controls, Table 10 shows that, except for tenured workers (with a small positive relationship with the probability of a wage reduction), the variables associated with the characteristics of the contracts are not significant. In addition, wage reductions are less likely for workers who work less than 30 hours and for those who work over 35 . We found no evidence of a link between the probability of a wage reduction and the size of the business unit. On the contrary, Bihan, Montornès and Heckel (2012) found that this probability is greater in small establishments. There is a positive but insignificant relationship between age and the possibility of a wage reduction.
} 
cant relationship between the probability of a wage increase and accumulated inflation. In the model without duration dummies, an increase in accumulated inflation of 1 percentage point ( $\mathrm{pp}$ ) increases the probability of an increase in wages by $3.6 \%$. Once we include the duration dummies, the same change in accumulated inflation increases the probability of an increase in wages to $0.7 \% .^{21}$

Table 11 shows the expected negative sign for the accumulated unemployment coefficient. Here, and without duration dummies, an increase in accumulated unemployment of $1 \mathrm{pp}$ decreases the probability of an increase in wages by $1.4 \%$. In contrast to the aforementioned effect for accumulated inflation, including duration dummies amplifies the impact of accumulated unemployment. Specifically, when accumulated unemployment increases by 1 $\mathrm{pp}$, the probability of an increase in wages decreases by $3.0 \%{ }^{22,23}$

\subsection{Results: Time- vs. State-dependency and contracts}

In this section we investigate the time and state component in the probability of observing changes in wages based on the characteristics of employment contracts.

Table 12 shows the estimated results, disaggregated by type of contracts, for the case of wage reductions. With the exception of flexible-hour contracts, which show a decrease in the probability of observing a wage reduction in January (with respect to December), the observed seasonality pattern is similar to that analyzed in subsection 6.1. As Table 12 reveals the negative relationship between the probability of a wage reduction and the variable associated with the months is considerably stronger throughout the year for this type of contract. The link between this probability and the duration variables is also stronger for flexible-hours contracts (on average it is three times higher).

[Table 12 about here.]

\footnotetext{
${ }^{21}$ In the sample the average accumulated inflation is of $0.81 \mathrm{pp}$. The $99 \%$ percentile is $4.9 \mathrm{pp}$ and the $1 \%$ percentile is $-1.0 \mathrm{pp}$.

${ }^{22}$ In the sample the average accumulated unemployment is of $0.04 \mathrm{pp}$. The $99 \%$ percentile is $1.4 \mathrm{pp}$ and the $1 \%$ percentile is - $1.1 \mathrm{pp}$.

${ }^{23}$ Regarding the controls, Table 11 shows that all the variables associated with the different characteristics of the contracts are not significant. In addition, there is a negative and significant relationship between the probability of an increase in wages and working hours for those who work over 25 hours a week. As in Bihan, Montornès and Heckel (2012), we detected weak evidence ( $10 \%$ of significance) of a negative link between the probability of a wage increase and the size of the business unit, when it has less than 50 persons employed. In the same line, and confirming our discussion in section 5 , the results show that age negatively affects the probability of a wage increase.
} 
The probability of wage reductions also exhibits some interesting state dependence components. In particular, and different from any other types in the contract space, labor contracts with flexible-hours show a statistically significant negative relationship with respect to accumulated unemployment. This indicates that - compared to fixed-hour contracts - flexible-hour contracts are now too downward rigid in the face of deteriorating aggregate economic conditions, captured in our regression analysis by rising accumulated unemployment.

It is again important to note that this important feature is associated with hour-flexibility and not so much with the contractual hours, because as Table 12 indicates, if anything, part-time contract wages tend to reduce less than fulltime contract wages when accumulated unemployment goes up.

With respect to wage increases, we find evidence of time dependence for all types of contracts considered. In this sense, and like when the estimate uses the pooled sample, Table 13 shows that in the case of wage increases, the seasonal pattern is also present when we break down the data by contractual characteristics.

The magnitude of the seasonal component for almost all types of contracts is comparable to the aggregate case mentioned in subsection 6.1 but is less pronounced for wage trajectories with flexible hours. The probability of observing a wage increase in January and July for workers with flexible hours is $14 \%$ and $6 \%$ higher than the probability of observing it in December; for the other contracts, they are $28 \%$ and $10 \%$ on average, respectively. In other words, the probability of observing a wage increase for contracts with flexible hours is flatter during the year and, therefore, is closer to Calvo's assumption of equal probability of change in each period.

[Table 13 about here.]

We observe something similar regarding the duration variables. For contracts with flexible hours, the probability of having an increase in wage after 11 months with no change is $25 \%$. On average, this probability for other types of contracts is almost double (41\%). This observation reinforces again the heterogeneity in wage adjustments between workers with different contractual terms.

In general, most types of contracts show dependence on the state associated with accumulated inflation and unemployment. The estimated coefficients have the expected sign and are similar between the types of contracts 
and those obtained with the aggregate data (subsection 6.1). In this sense, it is worth highlighting some findings, nevertheless.

There are two types of contracts for which the state dependency is associated only with one of the two macroeconomic variables considered. In particular, Table 13 shows that for contracts with flexible hours there is no significant relationship between the probability of a wage increase and accumulated unemployment.

Arguably, a stronger dependence on time compensates for this disconnection from the evolution of unemployment since the coefficients associated with the duration dummies are greater for workers with flexible hours compared to those with other types of contracts. Similarly, for fixed-term contracts the probability of a wage increase does not respond to accumulated inflation and, at the same time, its relation to accumulated unemployment is of lesser magnitude. In the case of flexible hours contracts, a stronger response to the duration of the wage trajectory accompanies this weaker dependency of the state.

The link between the likelihood of a wage increase and accumulated inflation for full-time contracts is twice as strong as for part-time contracts. Specifically, while for full-time contracts the positive relationship with accumulated inflation is one to one, an increase of the latter by 1 percentage point only increases the probability of a wage increase for part-time contracts by $0.5 \%{ }^{24}$

\section{Concluding Remarks}

Nominal wage rigidities not only impede the achievement of an optimal allocation of resources but also exacerbate unwanted fluctuations in unemployment and output, among other macroeconomic variables. These negative repercussions open the door to monetary policy interventions, which, however, can only counteract their effects when the determinants and magnitude of nominal wage rigidities are understood and measured correctly.

Understanding the way in which nominal wages are determined and the possible frictions that prevent them from adjusting to their optimum levels is, therefore, an important task for macroeconomists. However, only recently available databases, with high periodicity and a high level of disaggregation,

\footnotetext{
${ }^{24}$ In regard to the controls, Table 13 shows that only for tenured contracts the size of the business unit has a significant (negative) relationship with the probability of a wage increase.
} 
have allowed us to overcome the previous difficulties associated with understanding and measuring the dynamics of nominal wage changes.

This paper helps shed some light on the determinants and magnitude of nominal wage rigidities. We explored the dynamics of nominal wage rigidities in the Netherlands using a high frequency micro database with monthly information on nominal wages and the characteristics of the employment contracts of all employees in the period 2006-2012.

Several results stand out. We documented a clear seasonal pattern in the degree of nominal wage rigidity and a momentary increase in this rigidity immediately after the recent financial crisis. Our results also show a significant variability in the frequency of nominal wage changes in the different sectors, according to the size of the business unit and according to the age of the employee. In addition, we found that the hazard function has two peaks, one at 12 months and another at 24 months.

More importantly, and as a unique contribution, we find that certain characteristics of labor contracts play a role in determining the degree of nominal wage rigidity. In particular, characteristics such as the type of job, the working time, the duration of the contract and the status of the employee are an important source of heterogeneity in the nominal wage rigidity. As far as we know, this is the first time that the relationship between these contractual characteristics and the nominal wage rigidity is empirically uncovered.

In addition, our analysis provides evidence in favor of the theories of timeand state-dependence in the determination of nominal wages. We find that the probability of a change in the nominal wage depends on the duration of the wage trajectory (and the specific month of the year) but also on the evolution of aggregate macroeconomic variables (unemployment and inflation). This result is maintained, in general, when we perform the analysis separately for the different types of contracts, with some exceptions. In this sense, we find, on the one hand, that the probability of a wage increase in flexible hours contracts and in tenured contracts only responds to one of the two macroeconomic variables considered: inflation and unemployment, respectively. On the other hand, our results show that the probability of a nominal wage increase in full-time contracts shows a considerably higher response to changes in inflation and unemployment compared to the way part-time contracts respond. 


\section{References}

Altonji, Jg, and Pj Devereux. 2000. "The extent and consequences of downward nominal wage rigidity." Research and Labor Economics, 19(Worker Well-Being): 383-431. 3

Azariadis, Costas. 1975. "Implicit Contracts and Underemployment Equilibria." The Journal of Political Economy, 83(6): 1183-1202. 4

Barattieri, Alessandro, Susanto Basu, and Peter Gottschalk. 2014. "Some Evidence on the Importance of Sticky Wages." American Economic Journal: Macroeconomics, 6(1): 70-101. 3, 10, 11, 12, 13

Bihan, Hervé Le, Jérémi Montornès, and Thomas Heckel. 2012. "Sticky Wages: Evidence from Quarterly Microeconomic Data." American Economic Journal: Macroeconomics, 4(3): 1-32. 3, 4, 10, 12, 13, 14, 15, 19, 20, 21

Bolhaar, Jonneke, Arne Brouwers, and Bas Scheer. 2016. "De flexibele schil van de Nederlandse arbeidsmarkt: een analyse op basis van microdata." CPB Achtergronddocument. 2

Calvo, Guillermo. 1983. "Staggered prices in a utility-maximizing framework." Journal of monetary Economics, 12(1978): 383-398. 6

Campbell, Carl, and Kunal Kamlani. 1997. "The Reasons for Wage Rigidity: Evidence From a Survey of Firms." The Quarterly Journal of Economics, 112(3): 759-789. 4

Caplin, Andrew, and Daniel Spulber. 1987. "Menu Cost and the Neutrality of Money.” The Quarterly Journal of Economics, 102(4): 703-726. 6

Cecchetti, Stephen G. 1987. "Indexation and Incomes Policy: A Study of Wage Adjustment in Unionized Manufacturing." Journal of Labor Economics, 5(3): 391-412. 19

de Beer, Paul. 2016. “Onzeker werk. Achtergronden, gevolgen en strategie ten aanzien van flexibel werk.” De Burcht 14, Amsterdam. 2

de Beer, Paul, and Evert Verhulp. 2017. "Dertig vragen en antwoorden over flexibel werk." University of Amsterdam, Amsterdam Institute for Advanced Labour Studies. 2 
Deelen, Anja, and Wouter Verbeek. 2015. "Measuring Downward Nominal and Real Wage Rigidity - Why Methods Matter.” CPB Discussion Paper 315, 1-33. 3

Dickens, William T, Lorenz Goette, Erica L Groshen, Steinar Holden, Julian Messina, Mark E Schweitzer, Jarkko Turunen, and Melanie E Ward. 2007. "How Wages Change: Micro Evidence from the International Wage Flexibility Project." Journal of Economic Perspectives, 21(2): 195-214. 3

Ehrlich, Gabriel, and Joshua Montes. 2017. "Wage Rigidity and Employment Outcomes: Evidence from Administrative Data." Working Paper. 3

Euwals, Rob, Marloes de Graaf-Zijl, and Daniel van Vuuren. 2016. "Flexibiliteit op de arbeidsmarkt." CPB Policy Brief. 2

Fehr, Ernst, and Lorenz Goette. 2005. "Robustness and real consequences of nominal wage rigidity." Journal of Monetary Economics, 52(4): 779-804. 3, 6

Fischer, Stanley. 1977. "Long-Term Contracts, Rational Expectations, and the Optimal Money Supply Rule.” Journal of Political Economy, 85(1): 191-205. 4,6

Gottschalk, Peter. 2005. "Downward nominal-wage flexibility: real or measurement error?" Review of Economics and Statistics, 87(3): 556-568. 3, 10, 11,13

Hartog, Joop, Edwin Leuven, and Coen Teulings. 2002. "Wages and the bargaining regime in a corporatist setting: The Netherlands." European Journal of Political Economy, 18(2): 317-331. 8

Kahn, S. 1997. "Evidence of nominal wage stickiness from microdata." The American Economic Review, 87(5): 993-1008. 3

Kurmann, André, and Erika Mcentarfer. 2017. "Downward Wage Rigidity in the United States: New Evidence from Administrative Data." Working Paper, 50. 3

Lünnemann, Patrick, and Ladislav Wintr. 2009. "Wages are flexible, aren't they? evidence from monthly micro wage data." Working Paper Series, European Central Bank, 1074. 4, 10, 11, 12, 13, 14, 15 
Mclaughlin, Kenneth. 1994. "Rigid wages?" Journal of Monetary Economics, 34: 383-414. 3

Sigurdsson, Jósef, and Rannveig Sigurdardottir. 2016. "Time-dependent or state-dependent wage-setting? Evidence from periods of macroeconomic instability." Journal of Monetary Economics, 78: 50-66. 3, 4, 10, 11, 12, 13, 14, $15,19,20$

Smets, Frank, and Rafael Wouters. 2003. "An Estimated Dynamic Stochastic General Equilibrium Model of the Euro Area." Journal of the European Economic Association, 1(5): 1123-1175. 6

Stiglitz, Joseph. 1984. “Theories of wage rigidity.” NBER Working Paper, 1442. 4

Taylor, John B. 1980. “Aggregate Dynamics and Staggered Contracts.” Journal of Political Economy, 88(1): 1-23. 4, 6

van der Aa, Ruud, Dennis van Buren, and Thijs Viertelhauzen. 2015. "Motieven van werkgevers en werknemers voor flexibele contractvormen." In Dynamiek op de Nederlandse arbeidsmarkt. De focus op flexibilisering. , ed. Katja Chkalova, Anneke Goudswaard, Jos Sanders and Wendy Smits, 115127. Den Haag:Centraal Bureau voor Statistiek. 2

\section{Appendix}

\section{Additional figures}

[Figure 17 about here.]

\section{Additional tables}

[Table 14 about here.]

[Table 15 about here.]

[Table 16 about here.]

[Table 17 about here.]

[Table 18 about here.] 


\section{List of Figures}

1 Temporary employment. Percentage of dependent employment . 29

2 Part-time employment. Percentage of employment . . . . . . 30

3 Raw and adjusted wage trajectory $\ldots \ldots \ldots \ldots \ldots \ldots \ldots$

4 Hazard function of wage changes - Raw data . . . . . . . . . 31

5 Hazard function of wage changes - Adjusted data . . . . . . . . 32

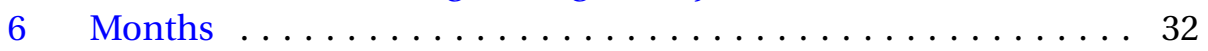

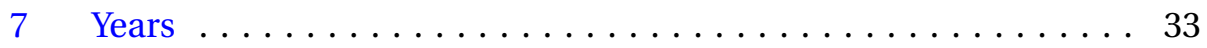

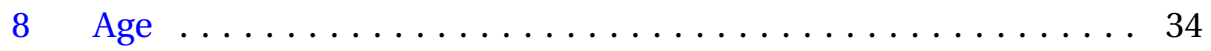

9 Participation of age groups $\ldots \ldots \ldots \ldots \ldots \ldots \ldots \ldots \ldots \ldots$

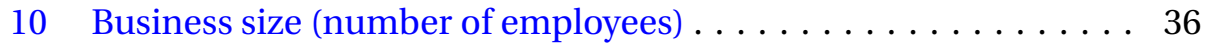

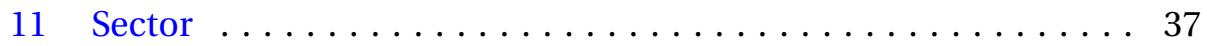

12 Participation of flexible and fixed contracts $\ldots \ldots \ldots \ldots \ldots 38$

13 Participation of tenured and untenured contracts . . . . . . . . 38

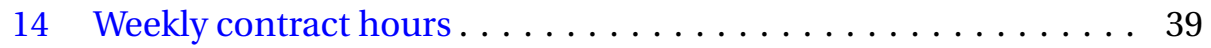

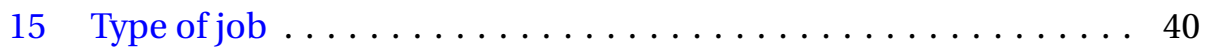

16 Share of "on-call" in the total number of workers . . . . . . . 40

17 Macroeconomic series for The Netherlands . . . . . . . . . . 41 
Figure 1: Temporary employment. Percentage of dependent employment 35

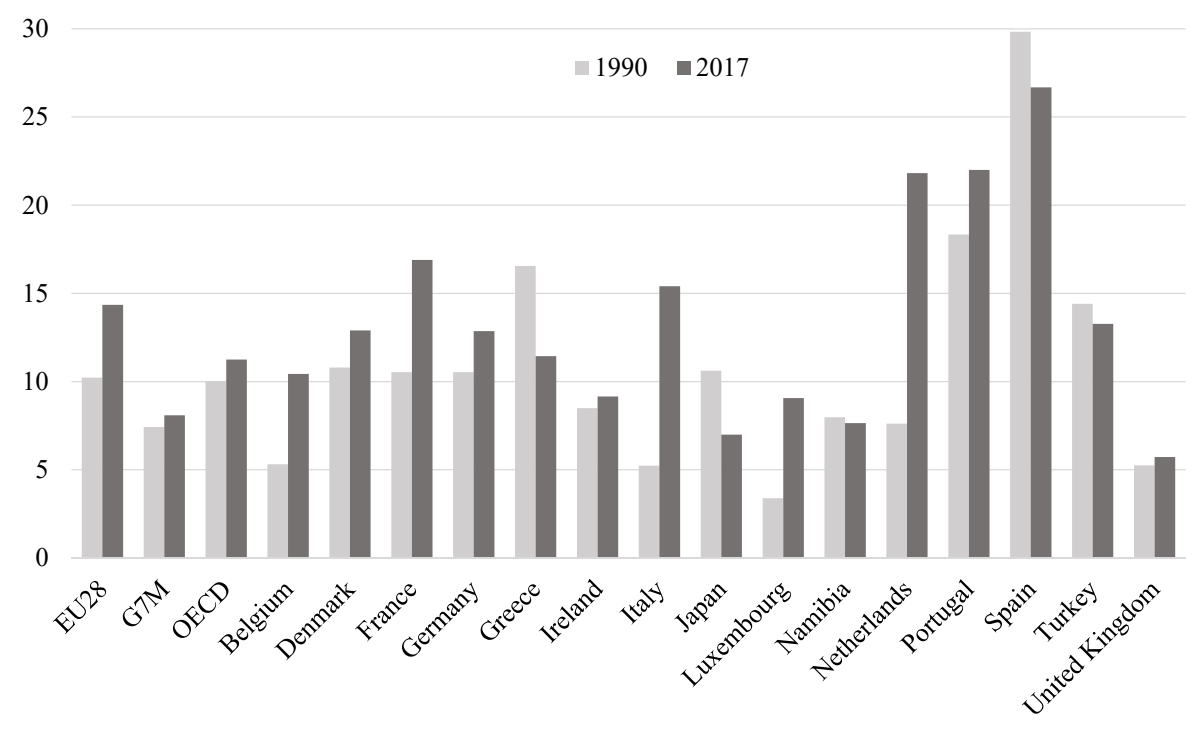

Source: OECD. Temporary employment includes wage and salary workers whose job has a pre-determined termination date. National definitions broadly conform to this generic definition, but may vary depending on national circumstances. This indicator is measured as percentage of dependent employees (i.e. wage and salary workers). 
Figure 2: Part-time employment. Percentage of employment

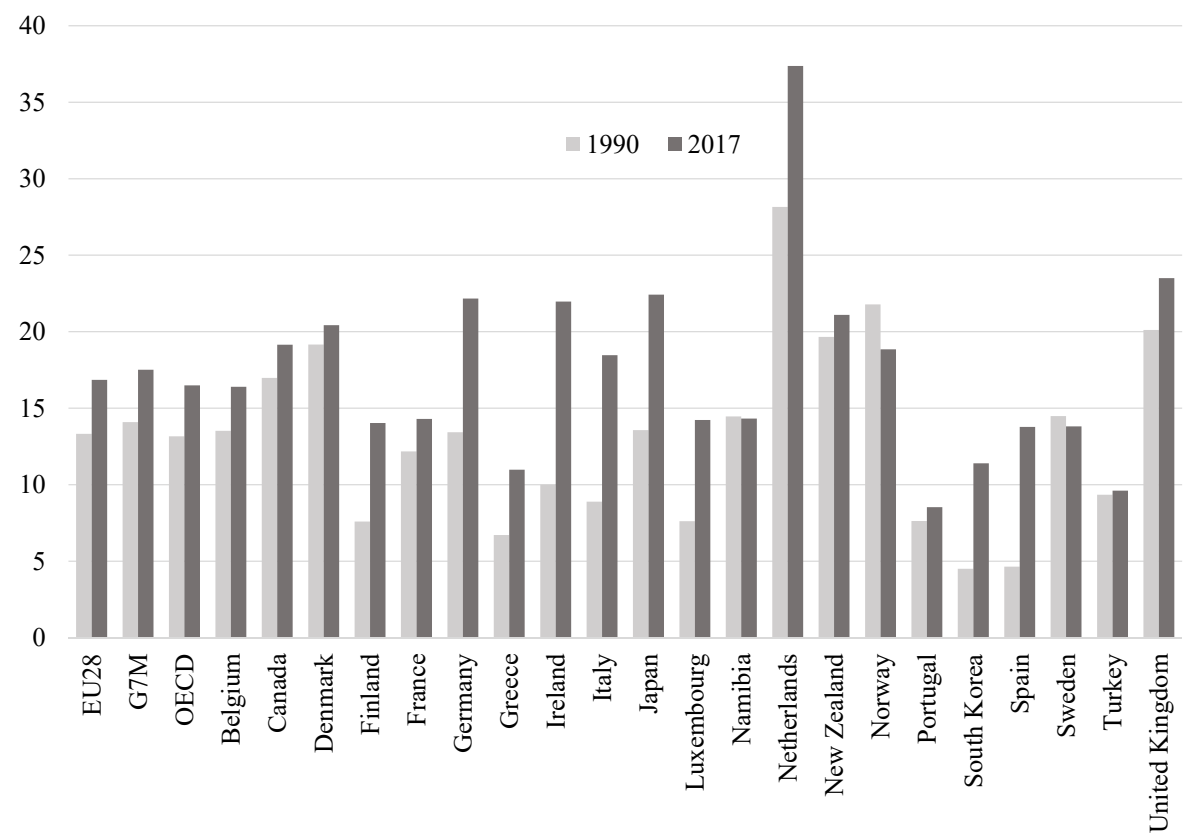

Source: OECD. Part-time employment is defined as people in employment (whether employees or selfemployed) who usually work less than 30 hours per week in their main job. Employed people are those aged 15 and over who report that they have worked in gainful employment for at least one hour in the previous week or who had a job but were absent from work during the reference week while having a formal job attachment. This indicator shows the proportion of persons employed part-time among all employed persons and is also called incidence of part-time employment. 
Figure 3: Raw and adjusted wage trajectory

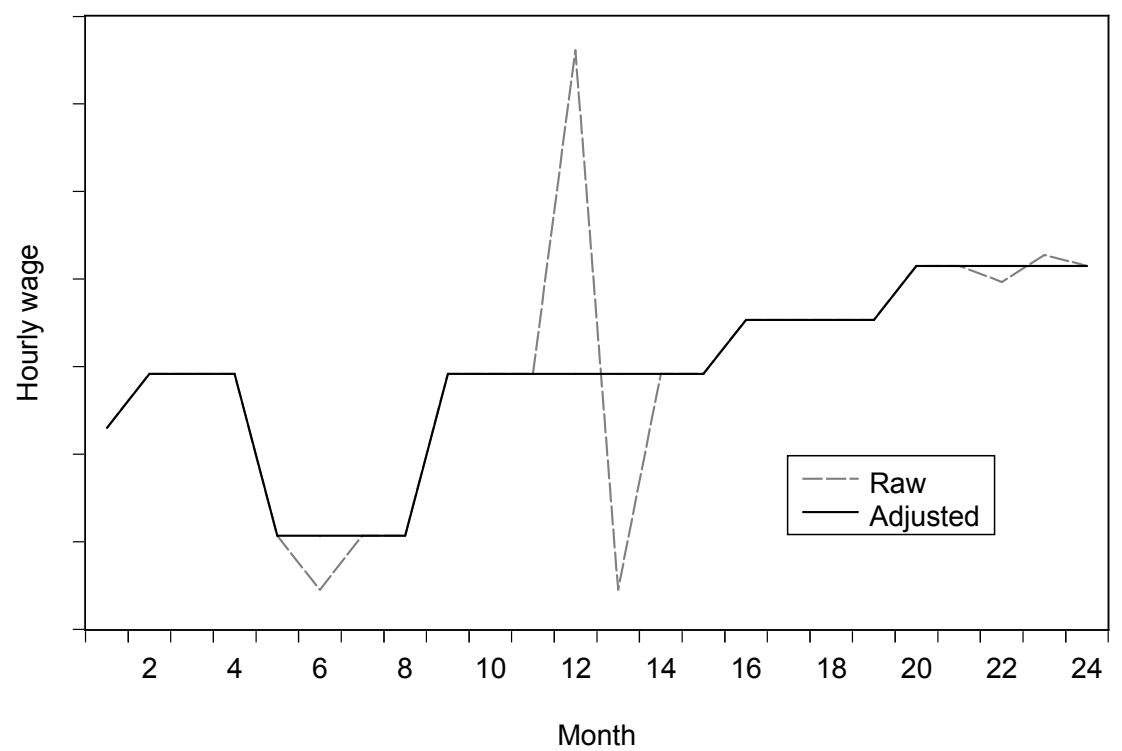

Note: The wage trajectory in this figure does not correspond to the wage trajectory of any individual in our sample nor in the population. The numbers were fabricated for illustrative purposes.

Figure 4: Hazard function of wage changes - Raw data

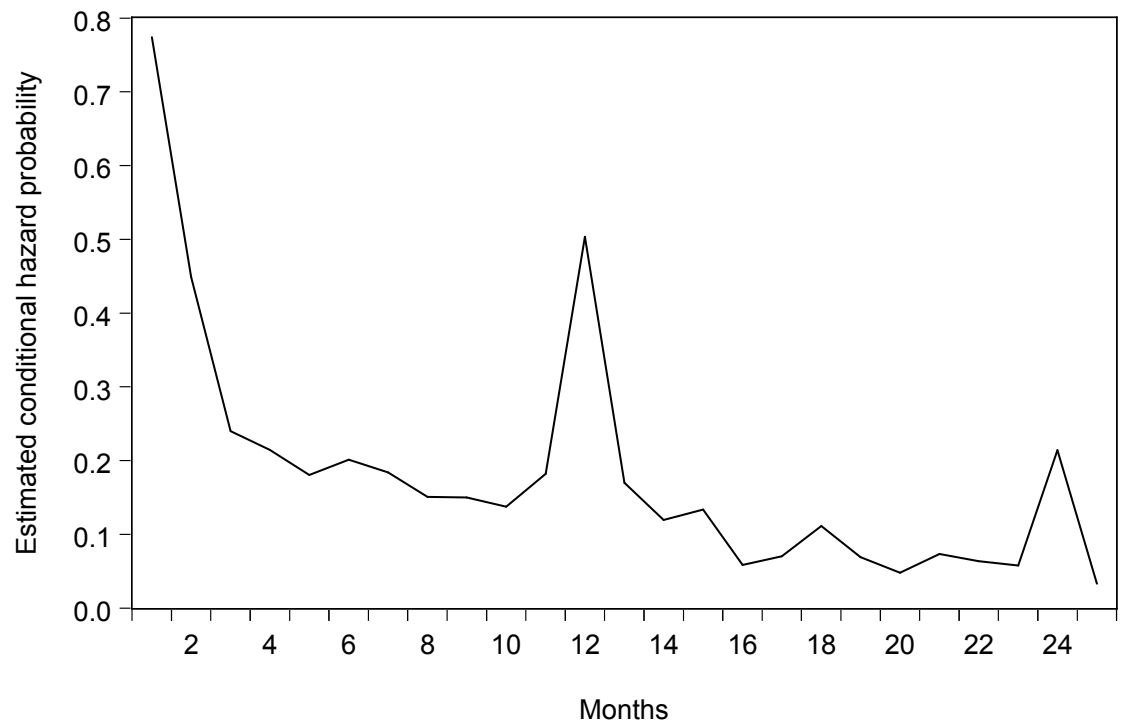

Source: Own calculations. 
Figure 5: Hazard function of wage changes - Adjusted data

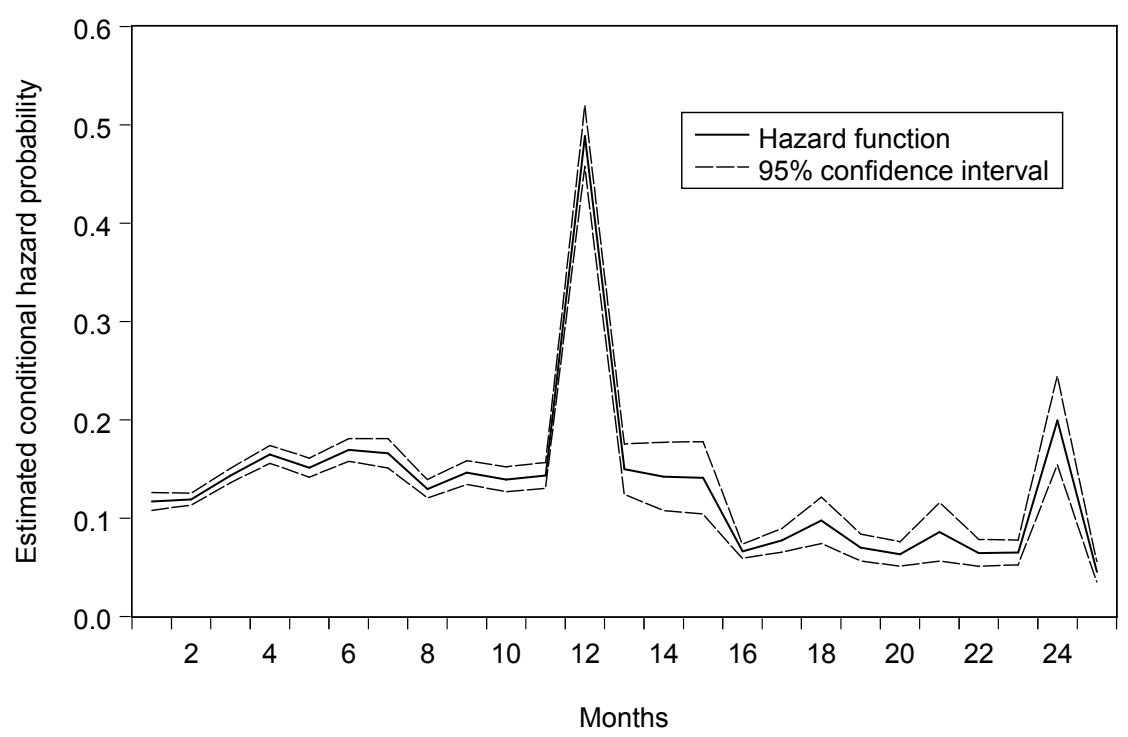

Source: Own calculations.

Figure 6: Months

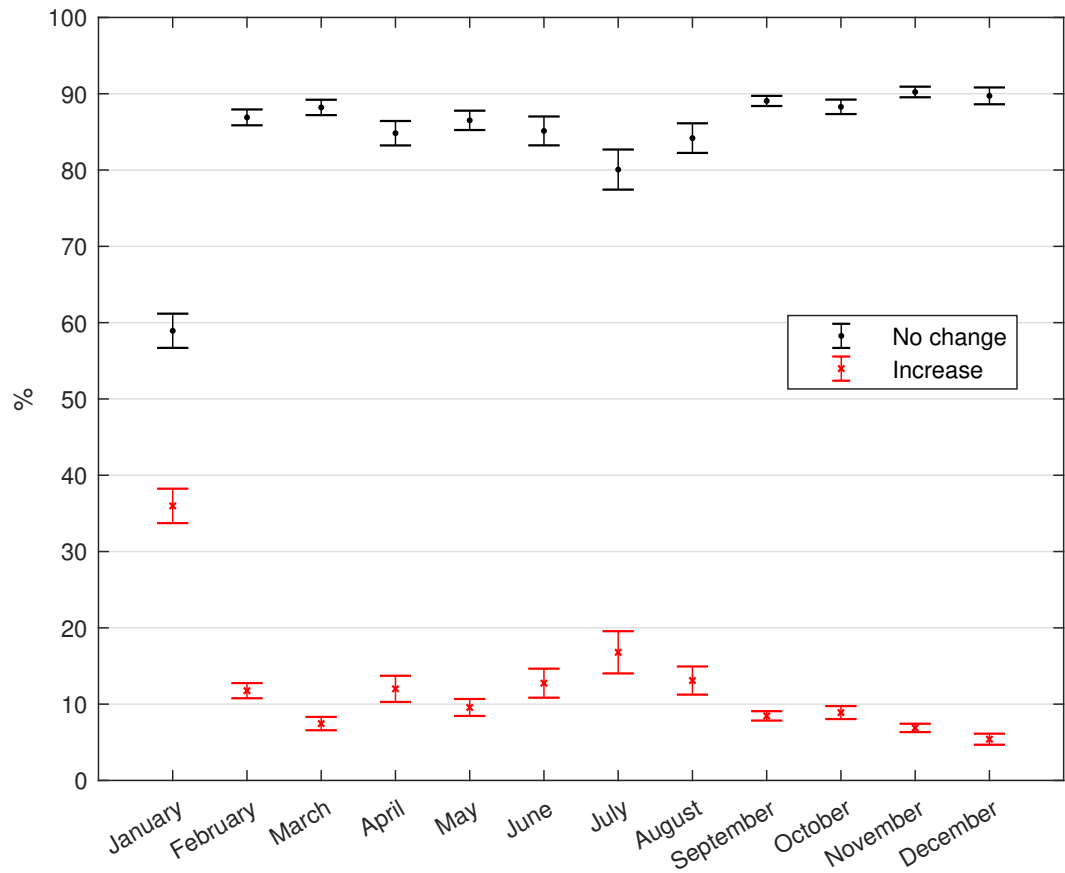

Source: Own calculations. 
Figure 7: Years

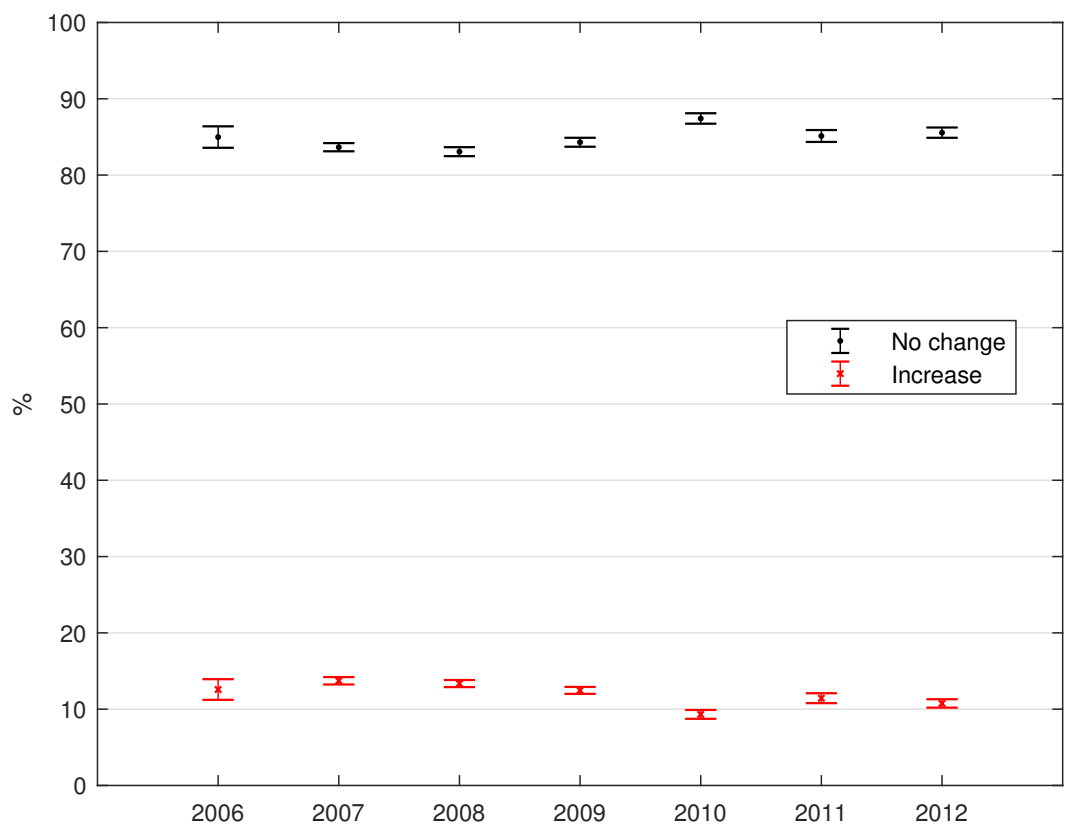

Source: Own calculations. 
Figure 8: Age

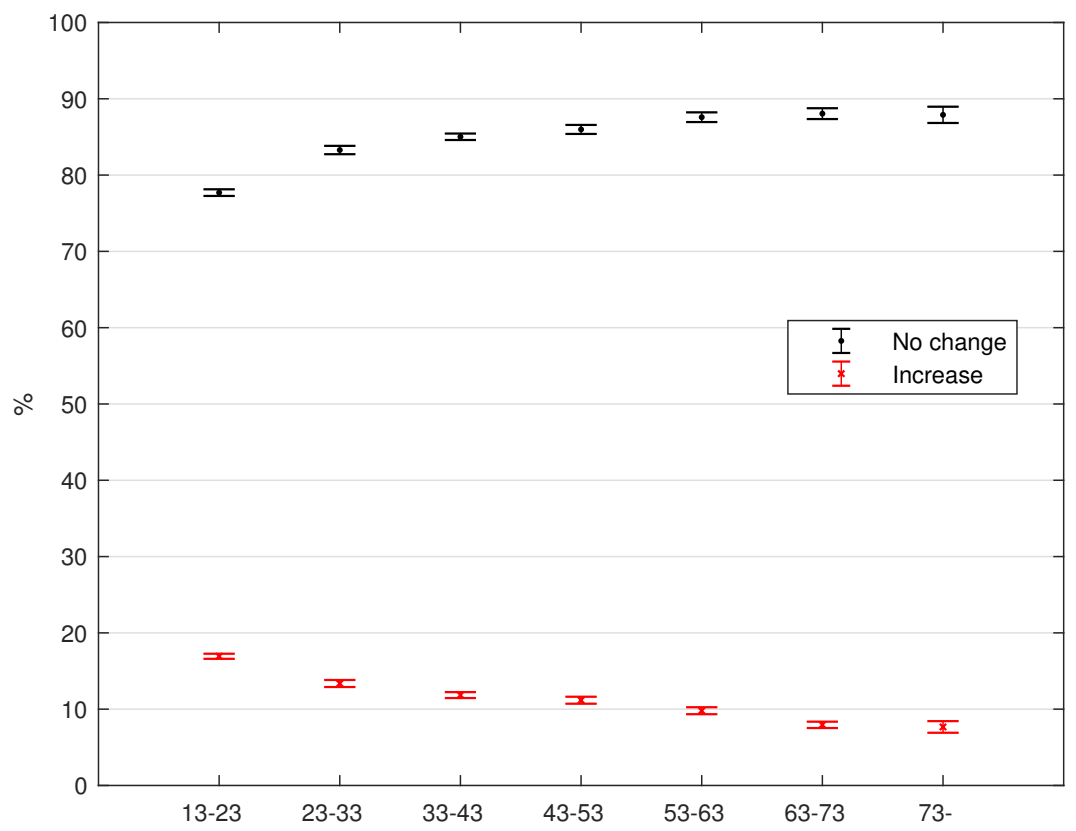

Source: Own calculations. 
Figure 9: Participation of age groups

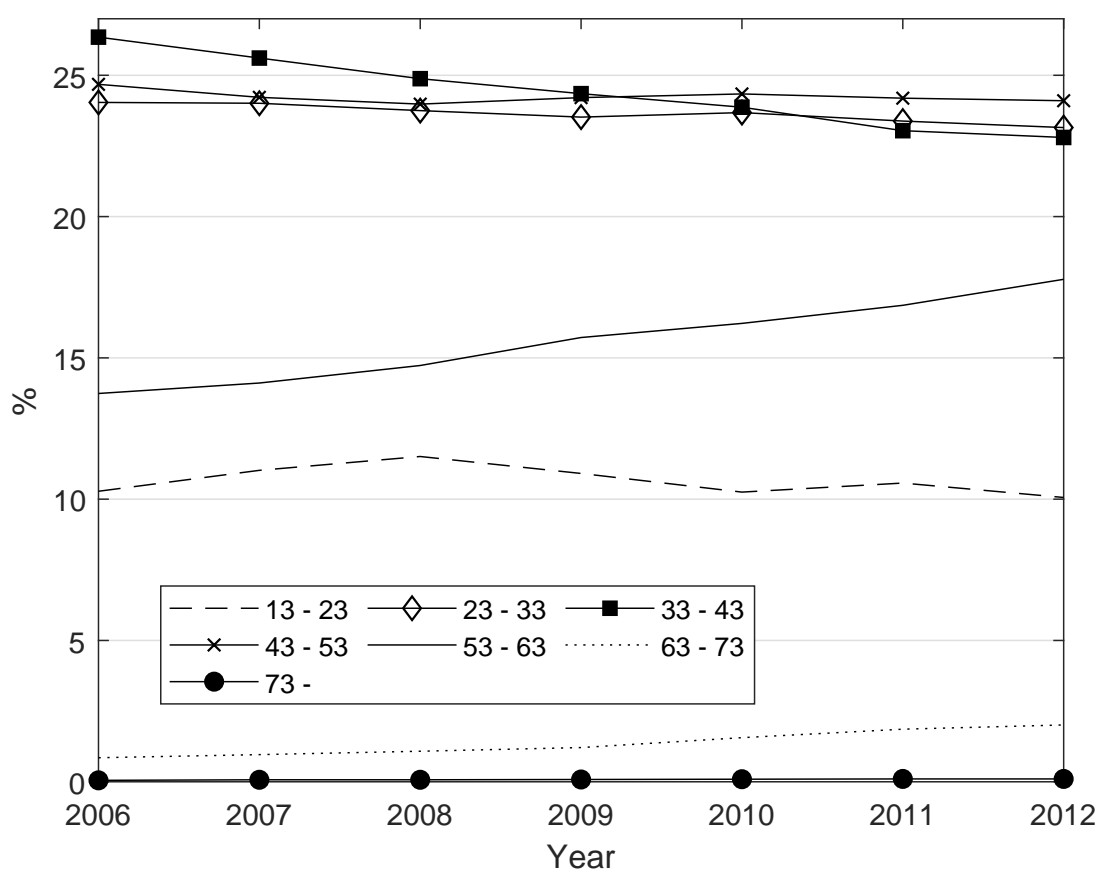


Figure 10: Business size (number of employees)

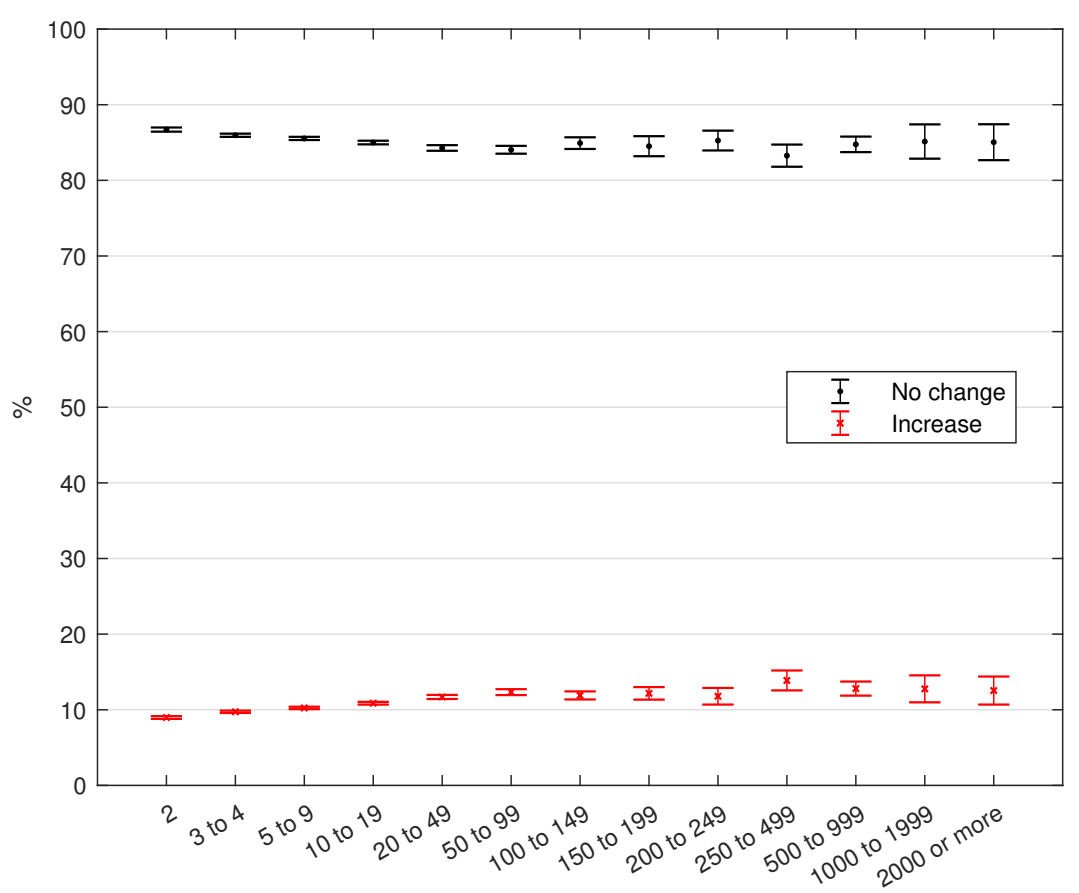

Source: Own calculations. 
Figure 11: Sector

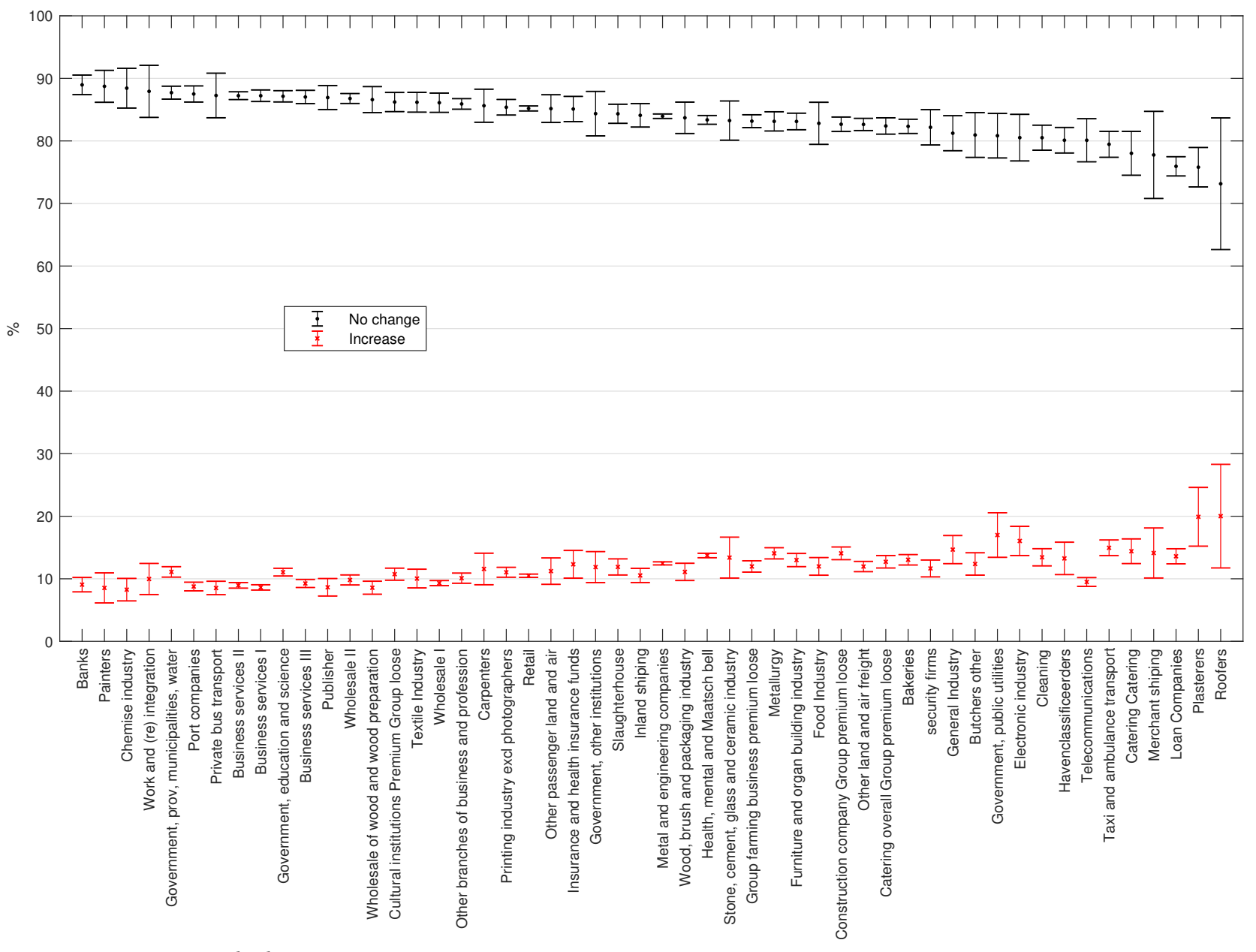

Source: Own calculations. 
Figure 12: Participation of flexible and fixed contracts

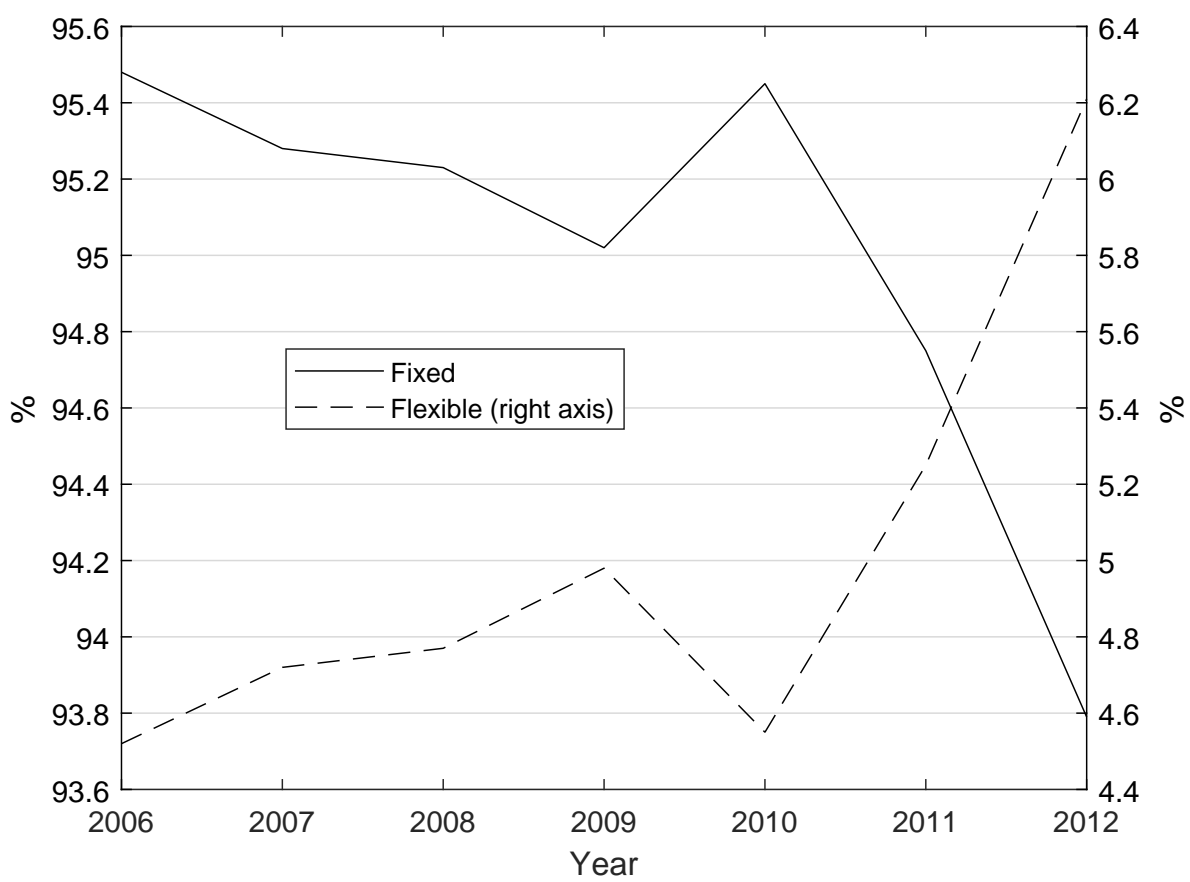

Figure 13: Participation of tenured and untenured contracts

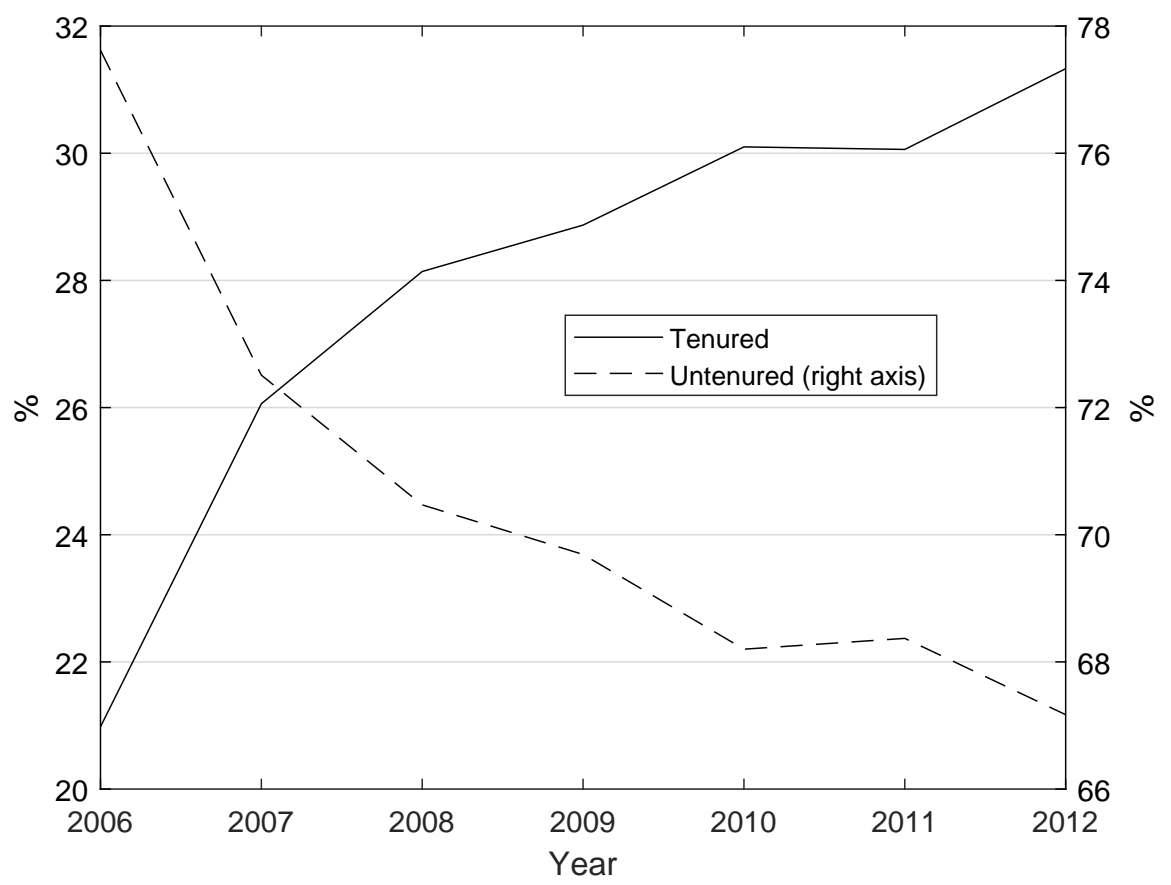


Figure 14: Weekly contract hours

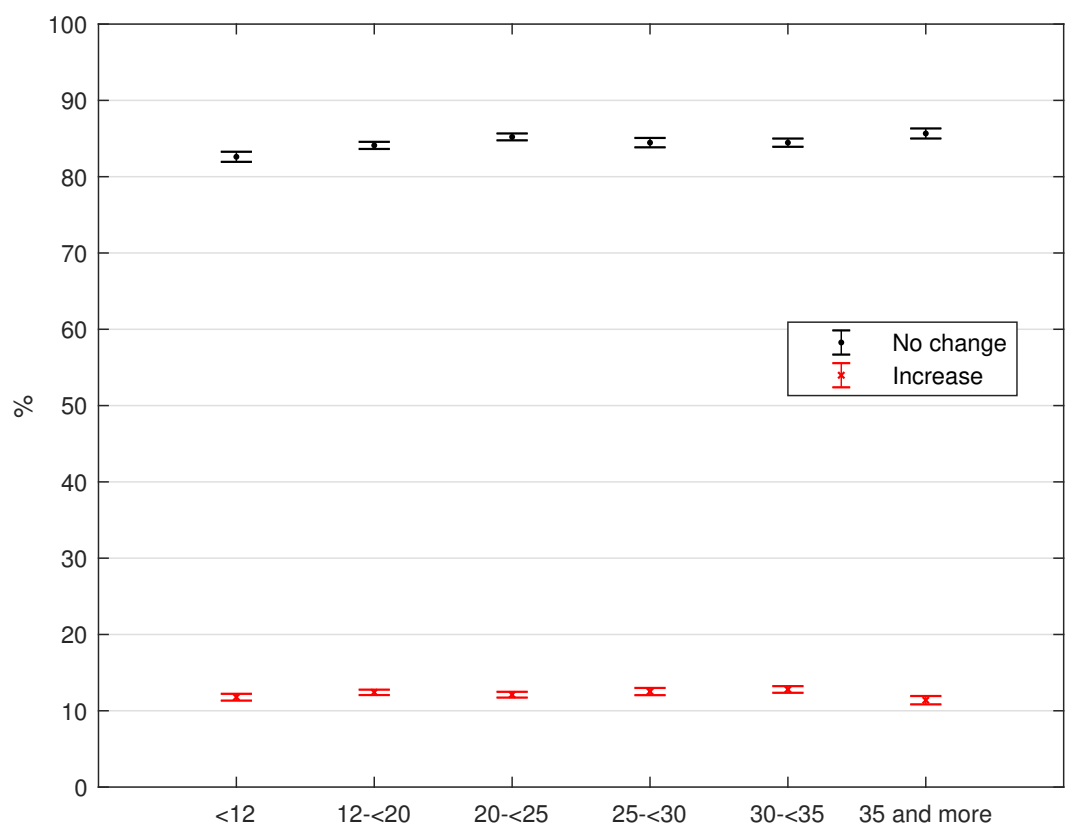

Source: Own calculations. 
Figure 15: Type of job

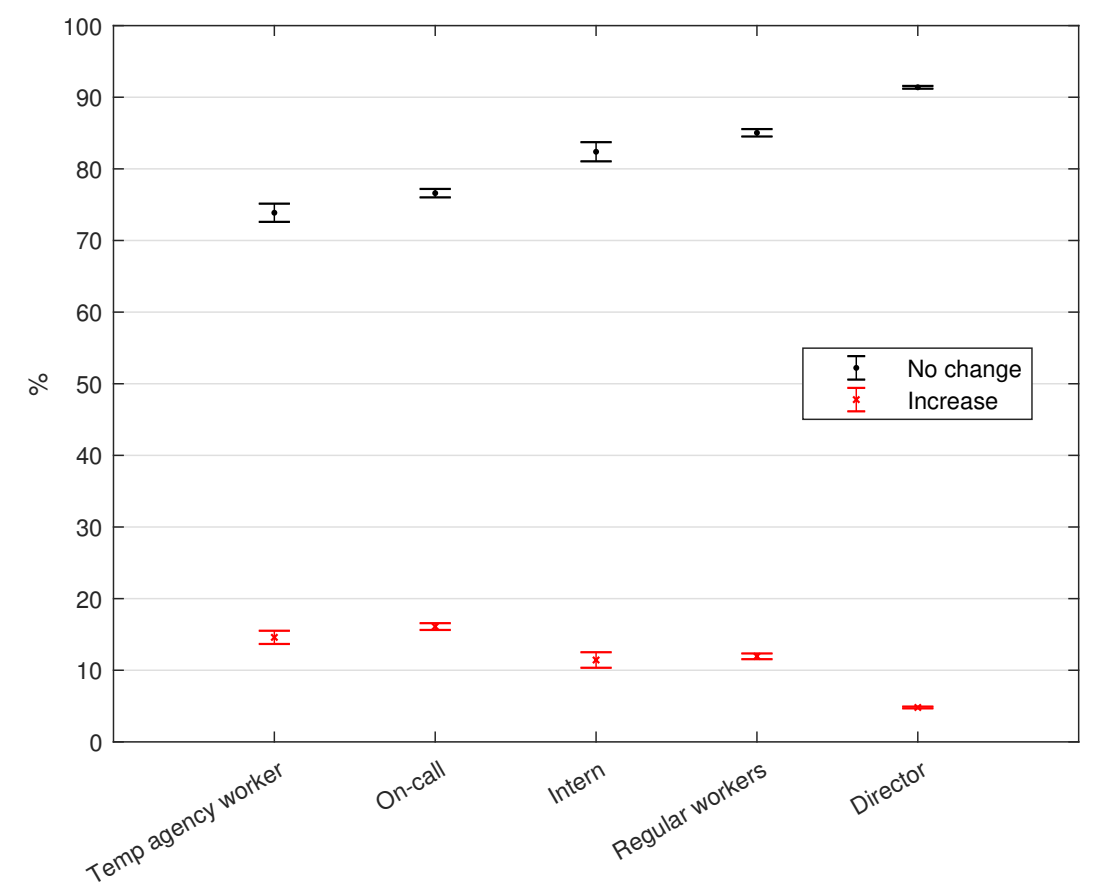

Source: Own calculations.

Figure 16: Share of "on-call" in the total number of workers

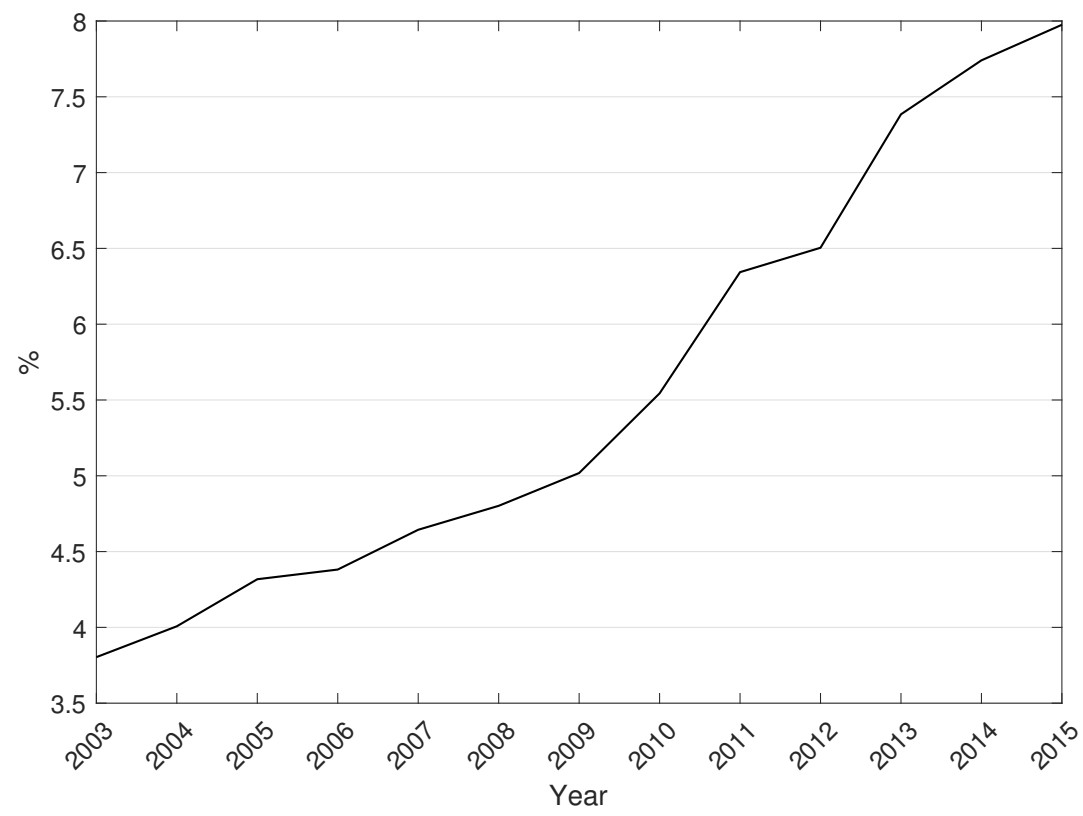

Source: CBS - Netherlands. 
Figure 17: Macroeconomic series for The Netherlands

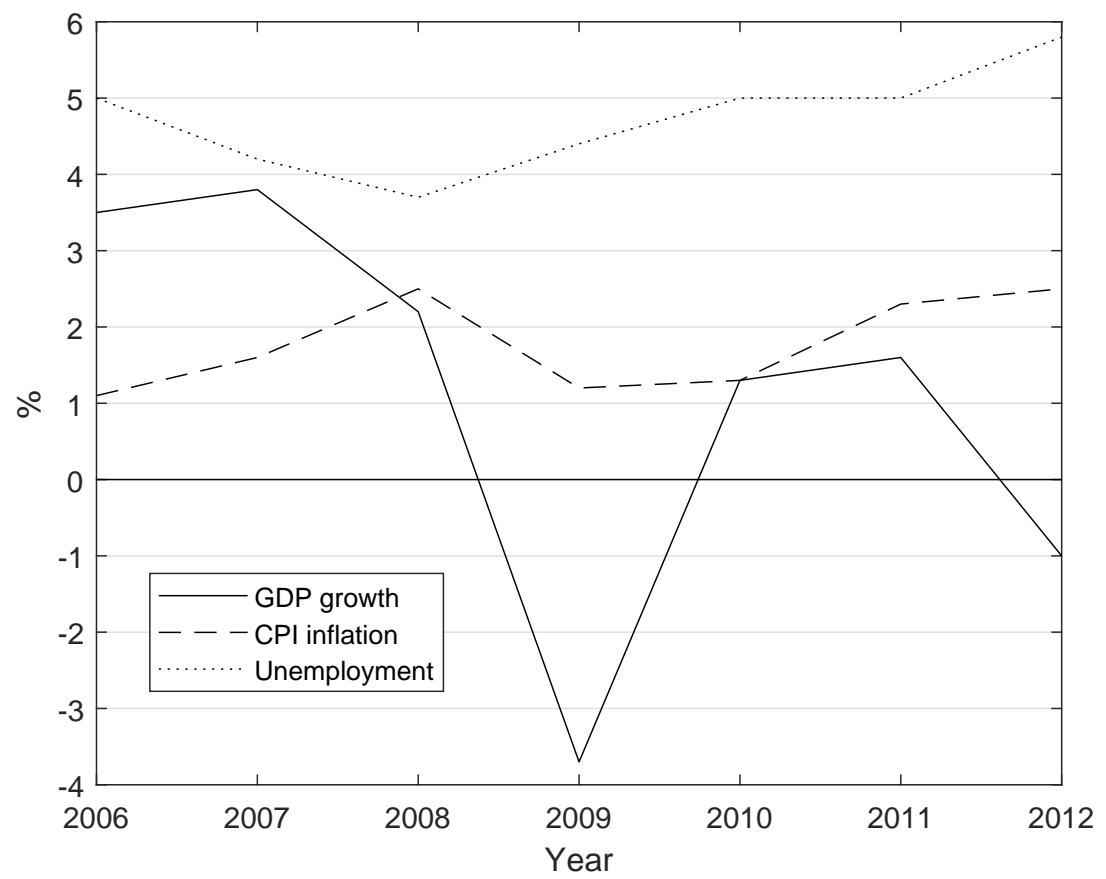




\section{List of Tables}

1 Composition of fixed-term contracts . . . . . . . . . . . 43

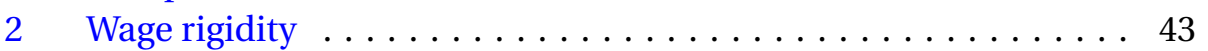

3 Month ......................... 44

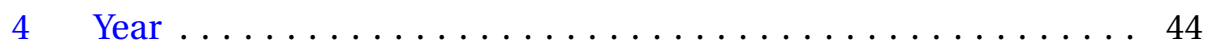

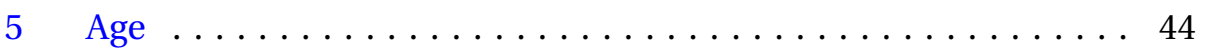

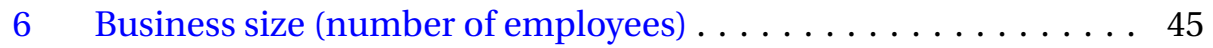

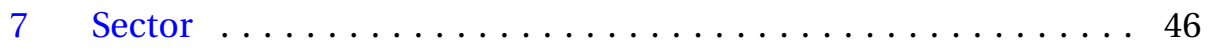

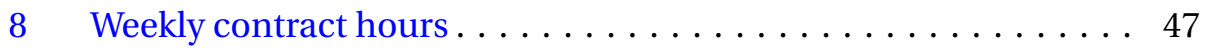

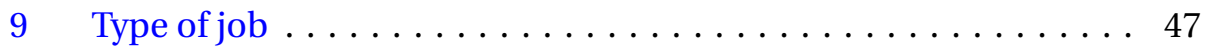

10 Probability of a wage reduction $\ldots \ldots \ldots \ldots \ldots \ldots \ldots \ldots 48$

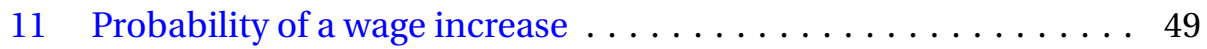

12 Probability of wage reductions by type of contract . . . . . . 50

13 Probability of wage increases by type of contract . . . . . . . 51

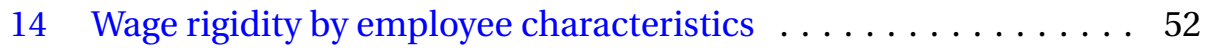

15 Distribution of contracts based on wage trajectory . . . . . . . 52

16 Distribution of contracts based on observations . . . . . . . . 52

17 Number of observations lost in each step of the data cleaning

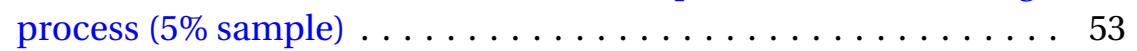

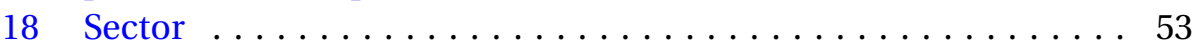


Table 1: Composition of fixed-term contracts

\begin{tabular}{lc}
\hline & Percentage \\
\hline On-call & $31 \%$ \\
Temporary, perspective of indefinite & $15 \%$ \\
Temp agency & $14 \%$ \\
Temporary $>=1$ year & $11 \%$ \\
Temporary $<1$ year & $10 \%$ \\
Temporary contract, no contract hours & $12 \%$ \\
Indefinite contract, no contract hours & $7 \%$ \\
\hline
\end{tabular}

Table 2: Wage rigidity

\begin{tabular}{|c|c|c|c|c|c|}
\hline & \multicolumn{3}{|c|}{ Frequency } & \multicolumn{2}{|c|}{ Average size } \\
\hline & Decrease & No change & Increase & Decrease & Increase \\
\hline Aggregate & $3.2[3.0 ; 3.3]$ & $84.9[84.6 ; 85.2]$ & $11.9[11.7 ; 12.1]$ & -8.9 & 4.8 \\
\hline \multicolumn{6}{|c|}{ Flexibility of Contractual Hours } \\
\hline Fixed & $3.0[2.8 ; 3.3]$ & $85.2[84.7 ; 85.7]$ & $11.8[11.4 ; 12.2]$ & -9.0 & 4.8 \\
\hline Flexible & $8.1[7.5 ; 8.7]$ & $76.1[75.5 ; 76.7]$ & $15.8[15.4 ; 16.3]$ & -9.5 & 5.8 \\
\hline \multicolumn{6}{|c|}{ Contracted Hours } \\
\hline Full-time & $2.9[2.6 ; 3.2]$ & $85.5[84.8 ; 86.1]$ & $11.6[11.1 ; 12.1]$ & -9.5 & 4.2 \\
\hline Part-time & $3.5[3.2 ; 3.7]$ & $84.3[83.9 ; 84.8]$ & $12.2[11.8 ; 12.6]$ & -8.7 & 5.4 \\
\hline \multicolumn{6}{|l|}{ Tenure } \\
\hline Tenured & $4.2[3.8 ; 4.7]$ & $82.7[81.9 ; 83.4]$ & $13.1[12.7 ; 13.5]$ & -11.5 & 7.0 \\
\hline Untenured & $2.9[2.7 ; 3.2]$ & $85.4[84.8 ; 85.9]$ & $11.7[11.3 ; 12.2]$ & -7.9 & 4.1 \\
\hline
\end{tabular}


Table 3: Month

\begin{tabular}{lccccc}
\hline & \multicolumn{3}{c}{ Frequency } & \multicolumn{2}{c}{ Average size } \\
& Decrease & No change & Increase & Decrease & Increase \\
\hline January & $5.1[4.5 ; 5.7]$ & $58.9[56.7 ; 61.2]$ & $36.0[33.7 ; 38.2]$ & -10.0 & 4.8 \\
February & $1.3[1.2 ; 1.5]$ & $86.9[85.9 ; 87.9]$ & $11.8[10.8 ; 12.8]$ & -10.9 & 6.7 \\
March & $4.3[3.8 ; 4.9]$ & $88.2[87.2 ; 89.2]$ & $7.4[6.6 ; 8.3]$ & -8.0 & 6.0 \\
April & $3.2[2.8 ; 3.6]$ & $84.8[83.2 ; 86.4]$ & $12.0[10.3 ; 13.7]$ & -9.1 & 4.4 \\
May & $3.9[3.5 ; 4.4]$ & $86.5[85.2 ; 87.8]$ & $9.6[8.5 ; 10.7]$ & -7.9 & 4.2 \\
June & $2.1[1.9 ; 2.3]$ & $85.1[83.2 ; 87.0]$ & $12.7[10.8 ; 14.7]$ & -10.7 & 4.0 \\
July & $3.1[2.9 ; 3.4]$ & $80.1[77.4 ; 82.7]$ & $16.8[14.0 ; 19.6]$ & -10.8 & 3.3 \\
August & $2.7[2.5 ; 3.0]$ & $84.2[82.2 ; 86.1]$ & $13.1[11.2 ; 14.9]$ & -8.6 & 4.3 \\
September & $2.5[2.3 ; 2.7]$ & $89.1[88.4 ; 89.7]$ & $8.5[7.8 ; 9.1]$ & -8.9 & 6.5 \\
October & $2.8[2.6 ; 3.0]$ & $88.3[87.3 ; 89.2]$ & $8.9[8.0 ; 9.7]$ & -8.2 & 4.9 \\
November & $2.9[2.6 ; 3.1]$ & $90.2[89.5 ; 90.9]$ & $6.9[6.3 ; 7.4]$ & -8.6 & 5.9 \\
December & $4.9[4.3 ; 5.5]$ & $89.7[88.6 ; 90.8]$ & $5.4[4.7 ; 6.1]$ & -8.6 & 5.2 \\
\hline
\end{tabular}

Marginal effects from multinomial logit models. All the numbers are percentages, and rows sum up to a $100 \%$. Confidence intervals in brackets. The last two columns represents the percentage change in nominal wage, conditional on a wage decrease or increase. The total number of observations is 13,174,294.

Table 4: Year

\begin{tabular}{cccccc}
\hline & \multicolumn{3}{c}{ Frequency } & \multicolumn{2}{c}{ Average size } \\
& Decrease & No change & Increase & Decrease & Increase \\
\hline 2006 & $2.4[2.2 ; 2.7]$ & $85.0[83.6 ; 86.4]$ & $12.6[11.2 ; 13.9]$ & -10.6 & 5.0 \\
2007 & $2.6[2.4 ; 2.9]$ & $83.7[83.1 ; 84.2]$ & $13.7[13.2 ; 14.2]$ & -11.1 & 4.8 \\
2008 & $3.6[3.2 ; 3.9]$ & $83.1[82.5 ; 83.7]$ & $13.4[12.9 ; 13.8]$ & -9.1 & 5.5 \\
2009 & $3.2[2.9 ; 3.5]$ & $84.3[83.7 ; 84.9]$ & $12.5[12.0 ; 12.9]$ & -8.6 & 4.9 \\
2010 & $3.3[3.0 ; 3.6]$ & $87.4[86.7 ; 88.1]$ & $9.3[8.7 ; 9.9]$ & -9.1 & 5.2 \\
2011 & $3.4[3.1 ; 3.8]$ & $85.1[84.3 ; 85.9]$ & $11.4[10.8 ; 12.1]$ & -7.9 & 4.3 \\
2012 & $3.7[3.3 ; 4.1]$ & $85.6[84.9 ; 86.2]$ & $10.8[10.2 ; 11.3]$ & -8.0 & 4.2 \\
\hline
\end{tabular}

Marginal effects from multinomial logit models. All the numbers are percentages, and rows sum up to a $100 \%$. Confidence intervals in brackets. The last two columns represents the percentage change in nominal wage, conditional on a wage decrease or increase. The total number of observations is 13,174,294.

Table 5: Age

\begin{tabular}{lccccc}
\hline & \multicolumn{3}{c}{ Frequency } & \multicolumn{2}{c}{ Average size } \\
& Decrease & No change & Increase & Decrease & Increase \\
\hline $13-23$ & $5.4[5.2 ; 5.6]$ & $77.7[77.3 ; 78.1]$ & $16.9[16.6 ; 17.3]$ & -10.0 & 9.1 \\
$23-33$ & $3.4[3.1 ; 3.6]$ & $83.3[82.7 ; 83.8]$ & $13.4[12.9 ; 13.8]$ & -10.0 & 5.2 \\
$33-43$ & $3.1[2.9 ; 3.4]$ & $85.0[84.6 ; 85.4]$ & $11.8[11.5 ; 12.2]$ & -8.8 & 4.4 \\
$43-53$ & $2.8[2.6 ; 3.1]$ & $86.0[85.4 ; 86.6]$ & $11.2[10.7 ; 11.6]$ & -7.7 & 3.8 \\
$53-63$ & $2.6[2.3 ; 2.9]$ & $87.6[86.9 ; 88.2]$ & $9.8[9.3 ; 10.3]$ & -8.1 & 3.8 \\
$63-73$ & $4.0[3.6 ; 4.4]$ & $88.1[87.3 ; 88.8]$ & $7.9[7.5 ; 8.4]$ & -11.3 & 5.7 \\
$73-$ & $4.4[3.9 ; 5.0]$ & $87.9[86.8 ; 89.0]$ & $7.7[6.9 ; 8.4]$ & -11.8 & 7.5 \\
\hline
\end{tabular}

Marginal effects from multinomial logit models. All the numbers are percentages, and rows sum up to a $100 \%$. Confidence intervals in brackets. The last two columns represents the percentage change in nominal wage, conditional on a wage decrease or increase. The total number of observations is 13,174,294. 
Table 6: Business size (number of employees)

\begin{tabular}{lccccc}
\hline & \multicolumn{2}{c}{ Frequency } & Average size \\
& Decrease & No change & Increase & Decrease & Increase \\
\hline 2 & $4.3[4.1 ; 4.5]$ & $86.7[86.4 ; 87.0]$ & $9.0[8.8 ; 9.2]$ & -9.1 & 7.9 \\
3 to 4 & $4.3[4.2 ; 4.4]$ & $86.0[85.8 ; 86.2]$ & $9.7[9.6 ; 9.9]$ & -9.0 & 7.3 \\
5 to 9 & $4.2[4.1 ; 4.3]$ & $85.5[85.3 ; 85.8]$ & $10.2[10.1 ; 10.4]$ & -8.5 & 6.5 \\
10 to 19 & $4.1[4.0 ; 4.3]$ & $85.0[84.8 ; 85.2]$ & $10.9[10.7 ; 11.0]$ & -8.7 & 6.0 \\
20 to 49 & $4.0[3.8 ; 4.2]$ & $84.3[83.9 ; 84.7]$ & $11.7[11.4 ; 12.0]$ & -9.5 & 5.5 \\
50 to 99 & $3.6[3.4 ; 3.9]$ & $84.0[83.5 ; 84.6]$ & $12.3[11.9 ; 12.7]$ & -10.8 & 5.1 \\
100 to 149 & $3.2[2.8 ; 3.6]$ & $84.9[84.1 ; 85.7]$ & $11.9[11.4 ; 12.4]$ & -10.3 & 5.1 \\
150 to 199 & $3.3[2.6 ; 4.1]$ & $84.5[83.2 ; 85.8]$ & $12.2[11.3 ; 13.0]$ & -9.0 & 4.7 \\
200 to 249 & $3.0[2.3 ; 3.6]$ & $85.3[84.0 ; 86.6]$ & $11.8[10.7 ; 12.9]$ & -8.7 & 4.4 \\
250 to 499 & $2.9[2.4 ; 3.3]$ & $83.3[81.8 ; 84.7]$ & $13.9[12.6 ; 15.2]$ & -7.8 & 3.8 \\
500 to 999 & $2.4[2.1 ; 2.8]$ & $84.8[83.7 ; 85.8]$ & $12.8[11.9 ; 13.7]$ & -6.7 & 3.5 \\
1000 to 1999 & $2.1[1.5 ; 2.7]$ & $85.1[82.9 ; 87.4]$ & $12.8[11.0 ; 14.5]$ & -12.3 & 4.7 \\
2000 or more & $2.4[1.4 ; 3.5]$ & $85.0[82.7 ; 87.4]$ & $12.5[10.7 ; 14.4]$ & -7.4 & 3.5 \\
\hline
\end{tabular}

Marginal effects from multinomial logit models. All the numbers are percentages, and rows sum up to a $100 \%$. Confidence intervals in brackets. The last two columns represents the percentage change in nominal wage, conditional on a wage decrease or increase. The total number of observations is 13,174,294. 
Table 7: Sector

\begin{tabular}{|c|c|c|c|c|c|}
\hline & \multicolumn{3}{|c|}{ Frequency } & \multicolumn{2}{|c|}{ Average size } \\
\hline & Decrease & No change & Increase & Decrease & Increase \\
\hline Banks & $2.0[1.2 ; 2.8]$ & $89.0[87.4 ; 90.5]$ & $9.1[7.9 ; 10.2]$ & -13.2 & 6.5 \\
\hline Painters & $2.7[2.1 ; 3.3]$ & $88.7[86.2 ; 91.3]$ & $8.5[6.1 ; 10.9]$ & -9.6 & 7.5 \\
\hline Chemise industry & $3.3[1.5 ; 5.1]$ & $88.4[85.3 ; 91.6]$ & $8.3[6.5 ; 10.1]$ & -6.2 & 4.6 \\
\hline Work and (re) integration & $2.1[-0.1 ; 4.3]$ & $87.9[83.8 ; 92.1]$ & $10.0[7.5 ; 12.5]$ & -8.9 & 3.4 \\
\hline Government, prov, municipalities, water & $1.2[0.8 ; 1.5]$ & $87.7[86.7 ; 88.8]$ & $11.1[10.3 ; 11.9]$ & -4.4 & 2.4 \\
\hline Port companies & $3.7[3.0 ; 4.5]$ & $87.5[86.2 ; 88.8]$ & $8.8[8.1 ; 9.5]$ & -7.7 & 6.1 \\
\hline Private bus transport & $4.2[0.6 ; 7.8]$ & $87.3[83.7 ; 90.8]$ & $8.5[7.5 ; 9.6]$ & -11.2 & 6.9 \\
\hline Business services II & $3.8[3.5 ; 4.1]$ & $87.2[86.6 ; 87.9]$ & $9.0[8.5 ; 9.4]$ & -9.1 & 6.8 \\
\hline Business services I & $4.1[3.3 ; 5.0]$ & $87.2[86.3 ; 88.2]$ & $8.6[8.2 ; 9.0]$ & -9.0 & 7.0 \\
\hline Government, education and science & $1.8[1.5 ; 2.1]$ & $87.1[86.2 ; 88.0]$ & $11.1[10.4 ; 11.7]$ & -12.8 & 5.4 \\
\hline Business services III & $3.7[3.2 ; 4.3]$ & $87.0[86.0 ; 88.1]$ & $9.3[8.6 ; 9.9]$ & -9.4 & 6.5 \\
\hline Publisher & $4.4[3.3 ; 5.5]$ & $86.9[85.0 ; 88.8]$ & $8.6[7.2 ; 10.0]$ & -10.3 & 8.9 \\
\hline Wholesale II & $3.4[3.1 ; 3.7]$ & $86.8[86.0 ; 87.6]$ & $9.8[9.0 ; 10.6]$ & -8.5 & 5.3 \\
\hline Wholesale of wood and wood preparation & $4.8[3.4 ; 6.3]$ & $86.6[84.5 ; 88.7]$ & $8.6[7.5 ; 9.6]$ & -8.0 & 6.6 \\
\hline Cultural institutions Premium Group loose & $3.0[2.3 ; 3.8]$ & $86.2[84.7 ; 87.7]$ & $10.7[9.8 ; 11.7]$ & -7.3 & 5.2 \\
\hline Textile Industry & $3.8[3.1 ; 4.5]$ & $86.2[84.6 ; 87.8]$ & $10.0[8.5 ; 11.5]$ & -9.7 & 7.1 \\
\hline Wholesale I & $4.6[3.0 ; 6.2]$ & $86.1[84.6 ; 87.6]$ & $9.3[8.9 ; 9.7]$ & -8.0 & 6.1 \\
\hline Other branches of business and profession & $4.0[3.4 ; 4.5]$ & $85.9[85.1 ; 86.8]$ & $10.1[9.3 ; 10.9]$ & -8.2 & 6.2 \\
\hline Carpenters & $2.8[1.9 ; 3.7]$ & $85.6[83.0 ; 88.3]$ & $11.6[9.1 ; 14.1]$ & -8.3 & 4.8 \\
\hline Printing industry excl photographers & $3.6[2.9 ; 4.2]$ & $85.4[84.1 ; 86.6]$ & $11.0[10.3 ; 11.8]$ & -12.3 & 5.3 \\
\hline Retail & $4.3[4.1 ; 4.5]$ & $85.2[84.8 ; 85.6]$ & $10.5[10.2 ; 10.8]$ & -9.0 & 6.8 \\
\hline Other passenger land and air & $3.6[2.3 ; 4.9]$ & $85.2[82.9 ; 87.4]$ & $11.2[9.1 ; 13.3]$ & -11.3 & 6.4 \\
\hline Insurance and health insurance funds & $2.6[1.3 ; 3.9]$ & $85.1[83.1 ; 87.1]$ & $12.3[10.1 ; 14.5]$ & -11.5 & 4.8 \\
\hline Government. other institutions & $3.8[2.4 ; 5.2]$ & $84.4[80.8 ; 87.9]$ & $11.9[9.4 ; 14.4]$ & -5.9 & 3.4 \\
\hline Slaughterhouse & $3.8[3.2 ; 4.3]$ & $84.3[82.8 ; 85.9]$ & $11.9[10.6 ; 13.2]$ & -8.4 & 6.8 \\
\hline Inland shiping & $5.4[4.4 ; 6.3]$ & $84.1[82.2 ; 86.0]$ & $10.5[9.4 ; 11.7]$ & -8.8 & 9.9 \\
\hline Metal and engineering companies & $3.6[3.3 ; 3.8]$ & $84.0[83.6 ; 84.3]$ & $12.5[12.2 ; 12.7]$ & -8.9 & 5.5 \\
\hline Wood, brush and packaging industry & $5.2[3.7 ; 6.7]$ & $83.7[81.2 ; 86.2]$ & $11.1[9.7 ; 12.5]$ & -8.1 & 6.0 \\
\hline Health, mental and Maatsch bell & $2.9[2.4 ; 3.4]$ & $83.4[82.7 ; 84.1]$ & $13.7[13.4 ; 14.1]$ & -8.8 & 4.3 \\
\hline Stone, cement, glass and ceramic industry & $3.4[2.5 ; 4.3]$ & $83.3[80.1 ; 86.4]$ & $13.4[10.1 ; 16.7]$ & -7.1 & 4.0 \\
\hline Group farming business premium loose & $4.9[4.3 ; 5.4]$ & $83.2[82.1 ; 84.2]$ & $12.0[11.1 ; 12.9]$ & -6.8 & 5.8 \\
\hline Metallurgy & $2.8[2.0 ; 3.6]$ & $83.1[81.6 ; 84.7]$ & $14.1[13.2 ; 15.0]$ & -9.9 & 3.6 \\
\hline Furniture and organ building industry & $3.9[3.0 ; 4.8]$ & $83.1[81.8 ; 84.4]$ & $13.0[11.9 ; 14.0]$ & -9.6 & 4.5 \\
\hline Food Industry & $5.2[3.0 ; 7.4]$ & $82.8[79.4 ; 86.2]$ & $12.0[10.6 ; 13.4]$ & -18.2 & 8.1 \\
\hline Construction company Group premium loose & $3.3[2.6 ; 3.9]$ & $82.7[81.5 ; 83.8]$ & $14.1[13.1 ; 15.1]$ & -13.1 & 4.0 \\
\hline Other land and air freight & $5.4[4.7 ; 6.1]$ & $82.6[81.7 ; 83.6]$ & $12.0[11.1 ; 12.8]$ & -7.9 & 5.7 \\
\hline Catering overall Group premium loose & $4.9[4.3 ; 5.5]$ & $82.4[81.1 ; 83.7]$ & $12.7[11.7 ; 13.7]$ & -7.3 & 6.6 \\
\hline Bakeries & $4.6[4.1 ; 5.2]$ & $82.3[81.2 ; 83.5]$ & $13.0[12.2 ; 13.9]$ & -8.3 & 6.2 \\
\hline security firms & $6.2[3.5 ; 8.9]$ & $82.2[79.4 ; 85.0]$ & $11.7[10.3 ; 13.0]$ & -9.5 & 6.1 \\
\hline General Industry & $4.1[3.3 ; 4.9]$ & $81.2[78.4 ; 84.0]$ & $14.7[12.4 ; 16.9]$ & -6.3 & 3.4 \\
\hline Butchers other & $6.7[4.4 ; 9.0]$ & $80.9[77.4 ; 84.5]$ & $12.4[10.6 ; 14.2]$ & -8.0 & 5.9 \\
\hline Government, public utilities & $2.2[1.9 ; 2.5]$ & $80.8[77.3 ; 84.4]$ & $17.0[13.4 ; 20.6]$ & -5.5 & 2.1 \\
\hline Electronic industry & $3.4[1.5 ; 5.3]$ & $80.5[76.8 ; 84.2]$ & $16.1[13.7 ; 18.4]$ & -7.3 & 4.6 \\
\hline Cleaning & $6.0[5.2 ; 6.9]$ & $80.5[78.5 ; 82.5]$ & $13.4[12.1 ; 14.8]$ & -8.1 & 4.6 \\
\hline Havenclassificeerders & $6.6[5.6 ; 7.7]$ & $80.1[78.1 ; 82.2]$ & $13.3[10.7 ; 15.8]$ & -4.2 & 6.8 \\
\hline Telecommunications & $10.4[7.3 ; 13.5]$ & $80.1[76.7 ; 83.5]$ & $9.5[8.8 ; 10.2]$ & -6.5 & 6.3 \\
\hline Taxi and ambulance transport & $5.6[4.5 ; 6.7]$ & $79.5[77.4 ; 81.5]$ & $15.0[13.7 ; 16.2]$ & -6.3 & 4.2 \\
\hline Catering Catering & $7.6[6.0 ; 9.2]$ & $78.0[74.5 ; 81.5]$ & $14.4[12.4 ; 16.4]$ & -31.9 & 16.7 \\
\hline Merchant shiping & $8.1[3.8 ; 12.4]$ & $77.8[70.8 ; 84.7]$ & $14.1[10.1 ; 18.1]$ & -29.5 & 22.4 \\
\hline Loan Companies & $10.5[9.6 ; 11.3]$ & $75.9[74.4 ; 77.5]$ & $13.6[12.4 ; 14.8]$ & -18.7 & 6.6 \\
\hline Plasterers & $4.3[1.5 ; 7.1]$ & $75.8[72.7 ; 78.9]$ & $19.9[15.2 ; 24.6]$ & -10.5 & 4.2 \\
\hline Roofers & $6.8[4.3 ; 9.4]$ & $73.2[62.6 ; 83.7]$ & $20.0[11.7 ; 28.3]$ & -13.2 & 9.3 \\
\hline
\end{tabular}

Marginal effects from multinomial logit models. All the numbers are percentages, and rows sum up to a $100 \%$. Confidence intervals in brackets. The last two columns represents the percentage change in nominal wage, conditional on a wage decrease or increase. The total number of observations is 13,174,294. 
Table 8: Weekly contract hours

\begin{tabular}{lccccc}
\hline & \multicolumn{2}{c}{ Frequency } & \multicolumn{2}{c}{ Average size } \\
& Decrease & No change & Increase & Decrease & Increase \\
\hline$<12$ & $5.6[5.3 ; 5.9]$ & $82.6[81.9 ; 83.3]$ & $11.8[11.3 ; 12.2]$ & -8.8 & 9.4 \\
$12-<20$ & $3.5[3.3 ; 3.7]$ & $84.1[83.6 ; 84.6]$ & $12.4[12.1 ; 12.8]$ & -8.8 & 5.4 \\
$20-<25$ & $2.7[2.5 ; 2.9]$ & $85.2[84.8 ; 85.7]$ & $12.1[11.7 ; 12.5]$ & -8.6 & 4.3 \\
$25-<30$ & $3.0[2.7 ; 3.3]$ & $84.5[83.8 ; 85.1]$ & $12.5[12.0 ; 13.0]$ & -8.2 & 4.3 \\
$30-<35$ & $2.7[2.4 ; 3.0]$ & $84.5[83.9 ; 85.0]$ & $12.8[12.4 ; 13.2]$ & -8.3 & 4.1 \\
35 and more & $3.0[2.6 ; 3.3]$ & $85.7[85.0 ; 86.3]$ & $11.4[10.8 ; 11.9]$ & -9.6 & 4.2 \\
\hline
\end{tabular}

Marginal effects from multinomial logit models. All the numbers are percentages, and rows sum up to a $100 \%$. Confidence intervals in brackets. The last two columns represents the percentage change in nominal wage, conditional on a wage decrease or increase. The total number of observations is 13,174,294.

Table 9: Type of job

\begin{tabular}{lccccc}
\hline & & Frequency & & \multicolumn{2}{c}{ Average size } \\
& Decrease & No change & Increase & Decrease & Increase \\
\hline Temp agency worker & $11.5[10.6 ; 12.5]$ & $73.9[72.6 ; 75.1]$ & $14.6[13.7 ; 15.5]$ & -20.8 & 5.9 \\
On-call & $7.3[6.8 ; 7.8]$ & $76.6[76.0 ; 77.2]$ & $16.1[15.6 ; 16.6]$ & -5.3 & 5.8 \\
Intern & $6.2[5.5 ; 6.9]$ & $82.4[81.0 ; 83.7]$ & $11.4[10.3 ; 12.5]$ & -24.9 & 22.3 \\
Regular workers & $3.0[2.8 ; 3.3]$ & $85.0[84.5 ; 85.6]$ & $11.9[11.5 ; 12.3]$ & -8.8 & 4.7 \\
Director & $3.8[3.7 ; 3.9]$ & $91.4[91.2 ; 91.6]$ & $4.8[4.7 ; 4.9]$ & -15.4 & 13.3 \\
\hline
\end{tabular}

Marginal effects from multinomial logit models. All the numbers are percentages, and rows sum up to a $100 \%$. Confidence intervals in brackets. The last two columns represents the percentage change in nominal wage, conditional on a wage decrease or increase. The total number of observations is 13,174,294. 
Table 10: Probability of a wage reduction

\begin{tabular}{|c|c|c|c|c|}
\hline & \multicolumn{2}{|c|}{ Panel A } & \multicolumn{2}{|c|}{ Panel B } \\
\hline & Parameter & Standard error & Parameter & Standard error \\
\hline \multicolumn{5}{|l|}{ "Time depedency" } \\
\hline \multicolumn{5}{|l|}{ Month } \\
\hline $\begin{array}{c}\text { January } \\
\text { February }\end{array}$ & $\begin{array}{c}0.029^{* * *} \\
-0.023^{* * *}\end{array}$ & $\begin{array}{l}0.005 \\
0.003\end{array}$ & $\begin{array}{c}0.028^{* * *} \\
-0.011^{* * *}\end{array}$ & $\begin{array}{l}0.005 \\
0.003\end{array}$ \\
\hline $\begin{array}{l}\text { February } \\
\text { March }\end{array}$ & $\begin{array}{l}-0.023 \\
-0.019 * * *\end{array}$ & $\begin{array}{l}0.003 \\
0.003\end{array}$ & $\begin{array}{l}-0.011 \\
-0.012^{* * *}\end{array}$ & $\begin{array}{l}0.003 \\
0.003\end{array}$ \\
\hline April & $-0.022^{* * *}$ & 0.002 & $-0.015^{* * *}$ & 0.002 \\
\hline May & $-0.016^{* * *}$ & 0.003 & $-0.012^{* * *}$ & 0.003 \\
\hline June & $-0.036^{* * *}$ & 0.003 & $-0.03^{* * *}$ & 0.003 \\
\hline July & $-0.017^{* * *}$ & 0.003 & $-0.011^{* * *}$ & 0.003 \\
\hline August & $-0.022^{* * *}$ & 0.003 & $-0.016^{* * *}$ & 0.003 \\
\hline Setpember & $-0.025^{* * *}$ & 0.003 & $-0.02^{* * *}$ & 0.003 \\
\hline October & $-0.024^{* * *}$ & 0.003 & $-0.02^{* * *}$ & 0.003 \\
\hline November & $-0.023^{* * *}$ & 0.003 & $-0.022^{* * *}$ & 0.003 \\
\hline \multicolumn{5}{|l|}{ Duration } \\
\hline 1 month & & & $0.024^{* * *}$ & 0.001 \\
\hline 2 months & & & $0.035^{* * *}$ & 0.002 \\
\hline 3 months & & & $0.055^{* * *}$ & 0.003 \\
\hline 4 months & & & $0.043^{* * *}$ & 0.002 \\
\hline 5 months & & & $0.032^{* * *}$ & 0.002 \\
\hline 6 months & & & $0.038^{* * *}$ & 0.002 \\
\hline 7 months & & & $0.032^{* * *}$ & 0.002 \\
\hline 8 months & & & $0.033^{* * *}$ & 0.002 \\
\hline 9 months & & & $0.038^{* * *}$ & 0.002 \\
\hline 10 months & & & $0.029^{* * *}$ & 0.002 \\
\hline 11 months & & & $0.044^{* * *}$ & 0.002 \\
\hline 12 months & & & $0.038^{* * *}$ & 0.002 \\
\hline \multicolumn{5}{|l|}{ "State dependency" } \\
\hline Accumulated inflation & $0.009^{* * *}$ & 0.001 & $0.005^{* * *}$ & 0.001 \\
\hline Accumulated unemployment & $-0.004^{* * *}$ & 0.001 & $-0.003^{* *}$ & 0.001 \\
\hline Accumulated productivity & 0.000 & 0.000 & 0.000 & 0.000 \\
\hline \multicolumn{5}{|l|}{ Employment policy } \\
\hline Part-time & 0.001 & 0.002 & 0.000 & 0.002 \\
\hline \multicolumn{5}{|l|}{ Employment relationship } \\
\hline \multirow{2}{*}{\multicolumn{5}{|c|}{ Type of contract }} \\
\hline & & & & \\
\hline Not applicable & 0.008 & 0.007 & 0.007 & 0.007 \\
\hline Untenured & $0.005^{* * *}$ & 0.001 & $0.004^{* * *}$ & 0.001 \\
\hline \multicolumn{5}{|l|}{ Type of relationship } \\
\hline Partnership & 0.001 & 0.003 & 0.001 & 0.003 \\
\hline Single & $-0.004^{* * *}$ & 0.001 & $-0.003^{* * *}$ & 0.001 \\
\hline & $0.003^{* * *}$ & 0.000 & $0.003^{* * *}$ & 0.000 \\
\hline \multicolumn{5}{|l|}{ Weekly contract hours } \\
\hline $12-<20$ & $-0.014^{* * *}$ & 0.001 & $-0.014^{* * *}$ & 0.001 \\
\hline $20-<25$ & $-0.011^{* * *}$ & 0.002 & $-0.011^{* * *}$ & 0.002 \\
\hline $25-<30$ & $-0.009^{* * *}$ & 0.003 & $-0.009^{* * *}$ & 0.003 \\
\hline $30-<35$ & 0.002 & 0.004 & 0.001 & 0.004 \\
\hline 35 and more & $0.011^{* *}$ & 0.005 & $0.01^{* *}$ & 0.005 \\
\hline \multicolumn{5}{|l|}{ Business size } \\
\hline 2 & -0.011 & 0.009 & -0.010 & 0.008 \\
\hline 3 to 4 & -0.010 & 0.009 & -0.010 & 0.008 \\
\hline 5 to 9 & -0.006 & 0.010 & -0.007 & 0.009 \\
\hline 10 to 19 & -0.002 & 0.010 & -0.003 & 0.009 \\
\hline 20 to 49 & -0.002 & 0.010 & -0.003 & 0.010 \\
\hline 50 to 99 & -0.002 & 0.011 & -0.004 & 0.010 \\
\hline 100 to 149 & 0.001 & 0.012 & -0.001 & 0.011 \\
\hline 150 to 199 & 0.000 & 0.013 & -0.003 & 0.012 \\
\hline 200 to 249 & 0.003 & 0.013 & 0.000 & 0.012 \\
\hline 250 to 499 & 0.002 & 0.014 & -0.002 & 0.013 \\
\hline 500 to 999 & -0.003 & 0.015 & -0.008 & 0.014 \\
\hline 1000 to 1999 & -0.006 & 0.015 & -0.012 & 0.013 \\
\hline 2000 or more & 0.007 & 0.018 & 0.001 & 0.017 \\
\hline Constant & $-0.073^{* * *}$ & 0.021 & $-0.109^{* * *}$ & 0.020 \\
\hline Observations & \multicolumn{2}{|c|}{$4,316,234$} & \multicolumn{2}{|c|}{$4,316,234$} \\
\hline
\end{tabular}

The reference wage trajectory is one from a worker with a full-time contract, fixed hours, tenured, married working in a small business unit. Standard errors (in parenthesis) clustered at business unit level. ${ }^{* *}$ Significant at the 1 percent level, ${ }^{* *}$ Significant at the 5 percent level, ${ }^{*}$ Significant at the 10 percent level. 
Table 11: Probability of a wage increase

\begin{tabular}{|c|c|c|c|c|}
\hline & \multicolumn{2}{|c|}{ Panel A } & \multicolumn{2}{|c|}{ Panel B } \\
\hline & Parameter & Standard error & Parameter & Standard error \\
\hline \multicolumn{5}{|l|}{ "Time depedency" } \\
\hline \multicolumn{5}{|l|}{ Month } \\
\hline $\begin{array}{c}\text { January } \\
\text { February }\end{array}$ & $\begin{array}{l}0.326^{* * *} \\
0.069^{* * *}\end{array}$ & $\begin{array}{l}0.015 \\
0.005\end{array}$ & $\begin{array}{l}0.281^{* * *} \\
0.072^{* * *}\end{array}$ & $\begin{array}{l}0.013 \\
0.006\end{array}$ \\
\hline $\begin{array}{l}\text { February } \\
\text { March }\end{array}$ & $0.017^{* * *}$ & $\begin{array}{l}0.005 \\
0.005\end{array}$ & $0.072^{* * *}$ & $\begin{array}{l}0.006 \\
0.005\end{array}$ \\
\hline April & $0.026^{* * *}$ & 0.010 & $0.062^{* * *}$ & 0.009 \\
\hline May & 0.000 & 0.006 & $0.034^{* * *}$ & 0.006 \\
\hline June & $0.029^{* * *}$ & 0.008 & $0.055^{* * *}$ & 0.007 \\
\hline July & $0.1^{* * *}$ & 0.015 & $0.105^{* * *}$ & 0.014 \\
\hline August & $0.069^{* * *}$ & 0.011 & $0.067^{* * *}$ & 0.010 \\
\hline Setpember & $0.017^{* * *}$ & 0.005 & $0.025^{* * *}$ & 0.005 \\
\hline October & $0.019^{* * *}$ & 0.004 & $0.036^{* * *}$ & 0.005 \\
\hline November & $-0.001^{* * *}$ & 0.003 & $0.01^{* * *}$ & 0.004 \\
\hline \multicolumn{5}{|l|}{ Duration } \\
\hline 1 month & & & $0.006^{*}$ & 0.003 \\
\hline 2 months & & & $0.025^{* * *}$ & 0.004 \\
\hline 3 months & & & $0.051^{* * *}$ & 0.005 \\
\hline 4 months & & & $0.049^{* * *}$ & 0.005 \\
\hline 5 months & & & $0.066^{* * *}$ & 0.006 \\
\hline 6 months & & & $0.086^{* * *}$ & 0.006 \\
\hline 7 months & & & $0.077^{* * *}$ & 0.005 \\
\hline 8 months & & & $0.087^{* * *}$ & 0.006 \\
\hline 9 months & & & $0.101^{* * *}$ & 0.007 \\
\hline 10 months & & & $0.114^{* * *}$ & 0.007 \\
\hline 11 months & & & $0.399 * * *$ & 0.015 \\
\hline 12 months & & & $0.139 * * *$ & 0.013 \\
\hline \multicolumn{5}{|l|}{ "State dependency" } \\
\hline Accumulated inflation & $0.036^{* * *}$ & 0.002 & $0.007^{* * *}$ & 0.002 \\
\hline Accumulated unemployment & $-0.014^{* * *}$ & 0.003 & $-0.03^{* * *}$ & 0.003 \\
\hline Accumulated productivity & 0.000 & 0.000 & 0.000 & 0.000 \\
\hline \multicolumn{5}{|l|}{ Employment policy } \\
\hline Part-time & -0.002 & 0.003 & -0.002 & 0.003 \\
\hline \multicolumn{5}{|l|}{ Employment relationship } \\
\hline Flexible & 0.009 & 0.006 & 0.009 & 0.006 \\
\hline \multicolumn{5}{|l|}{ Type of contract } \\
\hline Not applicable & -0.002 & 0.010 & -0.010 & 0.011 \\
\hline Untenured & 0.002 & 0.004 & -0.005 & 0.005 \\
\hline \multicolumn{5}{|l|}{ Type of relationship } \\
\hline Partnership & -0.006 & 0.005 & -0.006 & 0.005 \\
\hline Single & $-0.004^{* *}$ & 0.002 & -0.002 & 0.002 \\
\hline & $-0.016^{* * *}$ & 0.001 & $-0.014^{* * *}$ & 0.001 \\
\hline \multicolumn{5}{|l|}{ Weekly contract hours } \\
\hline $12-<20$ & 0.003 & 0.002 & 0.002 & 0.002 \\
\hline $20-<25$ & -0.002 & 0.003 & -0.003 & 0.003 \\
\hline $25-<30$ & $-0.007^{*}$ & 0.004 & $-0.007^{* *}$ & 0.004 \\
\hline $30-<35$ & -0.008 & 0.005 & $-0.008^{*}$ & 0.005 \\
\hline 35 and more & $-0.034^{* * *}$ & 0.007 & $-0.035^{* * *}$ & 0.006 \\
\hline \multicolumn{5}{|l|}{ Business size } \\
\hline 2 & $-0.05^{*}$ & 0.026 & $-0.048^{*}$ & 0.027 \\
\hline 3 to 4 & $-0.051^{*}$ & 0.027 & $-0.05^{*}$ & 0.028 \\
\hline 5 to 9 & $-0.056^{* *}$ & 0.028 & $-0.057^{* *}$ & 0.029 \\
\hline 10 to 19 & $-0.052^{*}$ & 0.029 & $-0.055^{*}$ & 0.030 \\
\hline 20 to 49 & $-0.051^{*}$ & 0.031 & $-0.053^{*}$ & 0.032 \\
\hline 50 to 99 & -0.052 & 0.033 & -0.055 & 0.035 \\
\hline 100 to 149 & -0.045 & 0.036 & -0.049 & 0.037 \\
\hline 150 to 199 & -0.040 & 0.038 & -0.043 & 0.039 \\
\hline 200 to 249 & -0.035 & 0.039 & -0.038 & 0.041 \\
\hline 250 to 499 & -0.017 & 0.042 & -0.020 & 0.044 \\
\hline 500 to 999 & -0.003 & 0.045 & -0.009 & 0.047 \\
\hline 1000 to 1999 & 0.028 & 0.043 & 0.025 & 0.045 \\
\hline 2000 or more & 0.041 & 0.046 & 0.043 & 0.048 \\
\hline Constant & \multirow{2}{*}{\multicolumn{2}{|c|}{$\begin{array}{c}0.72764 \\
4,707,989\end{array}$}} & $0.618^{* * *}$ & 0.066 \\
\hline Observations & & & \multicolumn{2}{|c|}{$4,707,989$} \\
\hline
\end{tabular}

The reference wage trajectory is one from a worker with a full-time contract, fixed hours, tenured, married, working in a small business unit. Standard errors (in parenthesis) clustered at business unit level. ${ }^{* * *}$ Significant at the 1 percent level, ${ }^{* *}$ Significant at the 5 percent level, ${ }^{*}$ Significant at the 10 percent level. 
Table 12: Probability of wage reductions by type of contract

\begin{tabular}{|c|c|c|c|c|c|c|c|c|c|c|c|c|}
\hline & \multicolumn{4}{|c|}{ Employment policy } & \multicolumn{4}{|c|}{ Employment relationship } & \multicolumn{4}{|c|}{ Type of contract } \\
\hline & \multicolumn{2}{|c|}{ Full-time } & \multicolumn{2}{|c|}{ Part-time } & \multicolumn{2}{|c|}{ Fixed } & \multicolumn{2}{|c|}{ Flexible } & \multicolumn{2}{|c|}{ Tenured } & \multicolumn{2}{|c|}{ Untenured } \\
\hline & Par. & St. error & Par. & St. error & Par. & St. error & Par. & St. error & Par. & St. error & Par. & St. error \\
\hline \multicolumn{13}{|l|}{$\begin{array}{l}\text { "Time- } \\
\text { depedency" } \\
\text { Month }\end{array}$} \\
\hline January & $0.034^{* * *}$ & 0.006 & $0.022^{* * *}$ & 0.005 & $0.029^{* * *}$ & 0.005 & -0.014 & 0.008 & $0.015^{* * *}$ & 0.005 & $0.031^{* * *}$ & 0.005 \\
\hline February & $-0.014^{* * *}$ & 0.003 & $-0.011^{* * *}$ & 0.003 & $-0.012^{* * *}$ & 0.003 & $-0.042^{* * *}$ & 0.005 & $-0.01^{* * *}$ & 0.003 & $-0.011^{* * *}$ & 0.003 \\
\hline March & $-0.014^{* * *}$ & 0.003 & $-0.01^{* * *}$ & 0.003 & $-0.011^{* * *}$ & 0.003 & $-0.051^{* * *}$ & 0.006 & $-0.015^{* * *}$ & 0.003 & $-0.01^{* * *}$ & 0.003 \\
\hline April & $-0.013^{* * *}$ & 0.003 & $-0.017^{* * *}$ & 0.003 & $-0.014^{* * *}$ & 0.002 & $-0.059^{* * *}$ & 0.005 & $-0.023^{* * *}$ & 0.003 & $-0.013^{* * *}$ & 0.003 \\
\hline May & $-0.009 * * *$ & 0.003 & $-0.015^{* * *}$ & 0.003 & $-0.011^{* * *}$ & 0.003 & $-0.062^{* * *}$ & 0.006 & $-0.021^{* * *}$ & 0.004 & $-0.01^{* * *}$ & 0.003 \\
\hline June & $-0.032^{* * *}$ & 0.004 & $-0.029^{* * *}$ & 0.003 & $-0.03^{* * *}$ & 0.003 & $-0.059^{* * *}$ & 0.005 & $-0.04^{* * *}$ & 0.004 & $-0.028^{* * *}$ & 0.003 \\
\hline July & $-0.014^{* * *}$ & 0.004 & $-0.009^{* * *}$ & 0.003 & $-0.01^{* * *}$ & 0.003 & $-0.049^{* * *}$ & 0.006 & $-0.014^{* * *}$ & 0.004 & $-0.01^{* * *}$ & 0.003 \\
\hline August & $-0.021^{* * *}$ & 0.004 & $-0.011^{* * *}$ & 0.003 & $-0.015^{* * *}$ & 0.003 & $-0.054^{* * *}$ & 0.006 & $-0.018^{* * *}$ & 0.004 & $-0.015^{* * *}$ & 0.003 \\
\hline Setpember & $-0.025^{* * *}$ & 0.004 & $-0.015^{* * *}$ & 0.003 & $-0.019^{* * *}$ & 0.003 & $-0.056^{* * *}$ & 0.006 & $-0.023^{* * *}$ & 0.004 & $-0.018^{* * *}$ & 0.003 \\
\hline October & $-0.025^{* * *}$ & 0.004 & $-0.016^{* * *}$ & 0.003 & $-0.019^{* * *}$ & 0.003 & $-0.056^{* * *}$ & 0.005 & $-0.026^{* * *}$ & 0.003 & $-0.018^{* * *}$ & 0.004 \\
\hline November & $-0.028^{* * *}$ & 0.004 & $-0.016^{* * *}$ & 0.003 & $-0.022^{* * *}$ & 0.003 & $-0.028^{* * *}$ & 0.005 & $-0.024^{* * *}$ & 0.003 & $-0.021^{* * *}$ & 0.004 \\
\hline \multicolumn{13}{|l|}{ Duration } \\
\hline 1 month & $0.02^{* * *}$ & 0.001 & $0.027^{* * *}$ & 0.001 & $0.022^{* * *}$ & 0.001 & $0.073^{* * *}$ & 0.003 & $0.038^{* * *}$ & 0.002 & $0.019^{* * *}$ & 0.001 \\
\hline 2 months & $0.028^{* * *}$ & 0.002 & $0.041^{* * *}$ & 0.002 & $0.032^{* * *}$ & 0.002 & $0.122^{* * *}$ & 0.005 & $0.057^{* * *}$ & 0.003 & $0.03^{* * *}$ & 0.002 \\
\hline 3 months & $0.05^{* * *}$ & 0.003 & $0.06^{* * *}$ & 0.003 & $0.052^{* * *}$ & 0.003 & $0.142^{* * *}$ & 0.006 & $0.083^{* * *}$ & 0.005 & $0.048^{* * *}$ & 0.003 \\
\hline 4 months & $0.033^{* * *}$ & 0.002 & $0.054^{* * *}$ & 0.003 & $0.041^{* * *}$ & 0.002 & $0.123^{* * *}$ & 0.005 & $0.067^{* * *}$ & 0.004 & $0.038^{* * *}$ & 0.002 \\
\hline 5 months & $0.027^{* * *}$ & 0.002 & $0.039 * * *$ & 0.002 & $0.03^{* * *}$ & 0.002 & $0.128^{* * *}$ & 0.008 & $0.059^{* * *}$ & 0.004 & $0.027^{* * *}$ & 0.002 \\
\hline 6 months & $0.03^{* * *}$ & 0.003 & $0.047^{* * *}$ & 0.002 & $0.035^{* * *}$ & 0.002 & $0.128^{* * *}$ & 0.010 & $0.064^{* * *}$ & 0.004 & $0.033^{* * *}$ & 0.003 \\
\hline 7 months & $0.025^{* * *}$ & 0.002 & $0.041^{* * *}$ & 0.002 & $0.03^{* * *}$ & 0.001 & $0.121^{* * *}$ & 0.010 & $0.058^{* * *}$ & 0.004 & $0.027^{* * *}$ & 0.001 \\
\hline 8 months & $0.026^{* * *}$ & 0.002 & $0.042^{* * *}$ & 0.003 & $0.031^{* * *}$ & 0.002 & $0.127^{* * *}$ & 0.009 & $0.058^{* * *}$ & 0.004 & $0.028^{* * *}$ & 0.002 \\
\hline 9 months & $0.028^{* * *}$ & 0.002 & $0.05^{* * *}$ & 0.003 & $0.036^{* * *}$ & 0.002 & $0.111^{* * *}$ & 0.011 & $0.065^{* * *}$ & 0.005 & $0.033^{* * *}$ & 0.002 \\
\hline 10 months & $0.023^{* * *}$ & 0.002 & $0.036^{* * *}$ & 0.002 & $0.027^{* * *}$ & 0.002 & $0.104^{* * *}$ & 0.011 & $0.06^{* * *}$ & 0.004 & $0.024^{* * *}$ & 0.002 \\
\hline 11 months & $0.041^{* * *}$ & 0.003 & $0.047^{* * *}$ & 0.003 & $0.041^{* * *}$ & 0.002 & $0.117^{* * *}$ & 0.013 & $0.068^{* * *}$ & 0.005 & $0.037^{* * *}$ & 0.002 \\
\hline 12 months & $0.029^{* * *}$ & 0.003 & $0.047^{* * *}$ & 0.002 & $0.036^{* * *}$ & 0.002 & $0.11^{* * *}$ & 0.012 & $0.06^{* * *}$ & 0.005 & $0.034^{* * *}$ & 0.002 \\
\hline \multicolumn{13}{|l|}{$\begin{array}{l}\text { "State- } \\
\text { dependency" }\end{array}$} \\
\hline $\begin{array}{r}\text { Accumulated } \\
\text { inflation }\end{array}$ & $0.006^{* * *}$ & 0.001 & $0.004^{* * *}$ & 0.001 & $0.005^{* * *}$ & 0.001 & $0.006^{* * *}$ & 0.002 & $0.008^{* * *}$ & 0.001 & $0.004^{* * *}$ & 0.001 \\
\hline $\begin{array}{r}\text { Accumulated } \\
\text { unemployment }\end{array}$ & -0.001 & 0.001 & $-0.004^{* * *}$ & 0.001 & $-0.003^{* * *}$ & 0.001 & $0.009^{* *}$ & 0.005 & -0.003 & 0.002 & $-0.002^{* *}$ & 0.001 \\
\hline $\begin{array}{r}\text { Accumulated } \\
\text { productivity }\end{array}$ & 0.000 & 0.000 & 0.000 & 0.000 & 0.000 & 0.000 & 0.000 & 0.000 & 0.000 & 0.000 & 0.000 & 0.000 \\
\hline \multicolumn{13}{|l|}{$\begin{array}{l}\text { Type } \\
\text { of relationship }\end{array}$} \\
\hline Partnership & -0.002 & 0.003 & 0.005 & 0.004 & 0.001 & 0.003 & -0.003 & 0.079 & 0.012 & 0.008 & 0.000 & 0.003 \\
\hline Single & $-0.004^{* * *}$ & 0.001 & -0.002 & 0.001 & $-0.004^{* * *}$ & 0.001 & $-0.024^{* *}$ & 0.012 & 0.001 & 0.003 & $-0.004^{* * *}$ & 0.001 \\
\hline age & $0.002^{* * *}$ & 0.000 & $0.003^{* * *}$ & 0.000 & $0.003^{* * *}$ & 0.000 & $0.01^{* * *}$ & 0.002 & $0.005^{* * *}$ & 0.001 & $0.003^{* * *}$ & 0.000 \\
\hline \multicolumn{13}{|l|}{$\begin{array}{l}\text { Weekly } \\
\text { contract hours }\end{array}$} \\
\hline $12-<20$ & & & $-0.012^{* * *}$ & 0.002 & $-0.01^{* * *}$ & 0.001 & $-0.024^{* * *}$ & 0.004 & $-0.021^{* * *}$ & 0.003 & $-0.009^{* * *}$ & 0.002 \\
\hline $20-<25$ & & & $-0.008^{* * *}$ & 0.003 & $-0.006^{* *}$ & 0.002 & $-0.032^{* * *}$ & 0.005 & $-0.025^{* * *}$ & 0.003 & -0.004 & 0.003 \\
\hline $25-<30$ & & & -0.005 & 0.004 & -0.003 & 0.003 & $-0.044^{* * *}$ & 0.005 & $-0.026^{* * *}$ & 0.004 & -0.002 & 0.003 \\
\hline $30-<35$ & $0.018^{* * *}$ & 0.004 & $0.01^{* *}$ & 0.005 & $0.008^{*}$ & 0.004 & $-0.058^{* * *}$ & 0.007 & $-0.018^{* * *}$ & 0.005 & $0.01^{* *}$ & 0.004 \\
\hline 35 and more & $0.033^{* * *}$ & 0.005 & $0.016^{* *}$ & 0.007 & $0.017^{* * *}$ & 0.006 & $-0.047^{* * *}$ & 0.007 & -0.006 & 0.006 & $0.019^{* * *}$ & 0.006 \\
\hline Business size & & & & & & & & & & & & \\
\hline 2 & -0.007 & 0.009 & -0.005 & 0.006 & -0.009 & 0.008 & -0.007 & 0.021 & 0.004 & 0.009 & $-0.016^{*}$ & 0.008 \\
\hline 3 to 4 & -0.007 & 0.009 & -0.006 & 0.006 & -0.009 & 0.008 & -0.007 & 0.020 & 0.008 & 0.008 & $-0.016^{*}$ & 0.008 \\
\hline 5 to 9 & -0.005 & 0.010 & 0.000 & 0.006 & -0.006 & 0.008 & -0.004 & 0.020 & 0.010 & 0.008 & -0.014 & 0.009 \\
\hline 10 to 19 & 0.000 & 0.010 & 0.002 & 0.007 & -0.003 & 0.009 & 0.008 & 0.021 & 0.012 & 0.008 & -0.010 & 0.009 \\
\hline 20 to 49 & -0.002 & 0.010 & 0.003 & 0.007 & -0.004 & 0.009 & 0.024 & 0.022 & 0.009 & 0.009 & -0.011 & 0.009 \\
\hline 50 to 99 & -0.003 & 0.011 & 0.004 & 0.008 & -0.005 & 0.010 & 0.035 & 0.027 & 0.014 & 0.010 & -0.013 & 0.010 \\
\hline 100 to 149 & -0.002 & 0.012 & 0.010 & 0.008 & -0.002 & 0.011 & 0.040 & 0.028 & $0.02 *$ & 0.011 & -0.011 & 0.010 \\
\hline 150 to 199 & -0.002 & 0.012 & 0.008 & 0.008 & -0.004 & 0.011 & 0.050 & 0.031 & $0.023^{* *}$ & 0.011 & -0.015 & 0.011 \\
\hline 200 to 249 & 0.005 & 0.013 & 0.006 & 0.009 & -0.001 & 0.012 & 0.075 & 0.054 & $0.043^{* * *}$ & 0.014 & -0.013 & 0.011 \\
\hline 250 to 499 & -0.005 & 0.013 & 0.010 & 0.009 & -0.004 & 0.012 & 0.049 & 0.035 & 0.016 & 0.011 & -0.013 & 0.011 \\
\hline 500 to 999 & -0.016 & 0.013 & 0.007 & 0.009 & -0.010 & 0.013 & $0.065^{* *}$ & 0.026 & 0.005 & 0.010 & -0.018 & 0.011 \\
\hline 1000 to 1999 & $-0.024^{* *}$ & 0.012 & 0.007 & 0.010 & -0.014 & 0.013 & $0.047^{*}$ & 0.027 & 0.003 & 0.010 & $-0.021^{*}$ & 0.011 \\
\hline 2000 or more & -0.013 & 0.019 & 0.023 & 0.015 & -0.001 & 0.017 & $0.073^{* * *}$ & 0.027 & 0.029 & 0.018 & -0.009 & 0.016 \\
\hline Constant & $-0.091^{* * *}$ & 0.020 & $-0.134^{* * *}$ & 0.019 & $-0.112^{* * *}$ & 0.020 & $-0.285^{* * *}$ & 0.057 & $-0.18^{* * *}$ & 0.031 & $-0.108^{* * *}$ & 0.020 \\
\hline Observations & 2,054 & 190 & 2,262 & ,044 & 4,195 & 818 & 120 & 416 & 771 & 440 & 3,48 & ,291 \\
\hline
\end{tabular}

Standard errors clustered at business unit level. ${ }^{* * *}$ Significant at the 1 percent level, ${ }^{* *}$ Significant at the 5 percent level, * Significant at the 10 percent level. 
Table 13: Probability of wage increases by type of contract

\begin{tabular}{|c|c|c|c|c|c|c|c|c|c|c|c|c|}
\hline & \multicolumn{4}{|c|}{ Employment policy } & \multicolumn{4}{|c|}{ Employment relationship } & \multicolumn{4}{|c|}{ Type of contract } \\
\hline & \multicolumn{2}{|c|}{ Full-time } & \multicolumn{2}{|c|}{ Part-time } & \multicolumn{2}{|c|}{ Fixed } & \multicolumn{2}{|c|}{ Flexible } & \multicolumn{2}{|c|}{ Tenured } & \multicolumn{2}{|c|}{ Untenured } \\
\hline & Par. & St. error & Par. & St. error & Par. & St. error & Par. & St. error & Par. & St. error & Par. & St. error \\
\hline \multicolumn{13}{|l|}{$\begin{array}{l}\text { "Time- } \\
\text { depedency" } \\
\text { Month }\end{array}$} \\
\hline January & $0.311^{* * *}$ & 0.014 & $0.256^{* * *}$ & 0.013 & $0.285^{* * *}$ & 0.014 & $0.136^{* * *}$ & 0.011 & $0.263^{* * *}$ & 0.015 & $0.285^{* * *}$ & 0.015 \\
\hline February & $0.08^{* * *}$ & 0.009 & $0.067^{* * *}$ & 0.005 & $0.071^{* * *}$ & 0.006 & $0.1^{* * *}$ & 0.025 & $0.085^{* * *}$ & 0.006 & $0.07^{* * *}$ & 0.007 \\
\hline March & $0.036^{* * *}$ & 0.007 & $0.042^{* * *}$ & 0.004 & $0.038^{* * *}$ & 0.005 & $0.042^{* * *}$ & 0.009 & $0.043^{* * *}$ & 0.003 & $0.038^{* * *}$ & 0.005 \\
\hline April & $0.073^{* * *}$ & 0.012 & $0.053^{* * *}$ & 0.006 & $0.062^{* * *}$ & 0.009 & $0.045^{* * *}$ & 0.010 & $0.064^{* * *}$ & 0.014 & $0.062^{* * *}$ & 0.009 \\
\hline May & $0.027^{* * *}$ & 0.006 & $0.041^{* * *}$ & 0.007 & $0.034^{* * *}$ & 0.006 & $0.041^{* * *}$ & 0.013 & $0.055^{* * *}$ & 0.006 & $0.03^{* * *}$ & 0.007 \\
\hline June & $0.064^{* * *}$ & 0.011 & $0.049^{* * *}$ & 0.006 & $0.056^{* * *}$ & 0.008 & $0.033^{* * *}$ & 0.012 & $0.048^{* * *}$ & 0.005 & $0.058^{* * *}$ & 0.009 \\
\hline July & $0.101^{* * *}$ & 0.011 & $0.11^{* * *}$ & 0.017 & $0.106^{* * *}$ & 0.014 & $0.063^{* * *}$ & 0.013 & $0.1^{* * *}$ & 0.011 & $0.108^{* * *}$ & 0.015 \\
\hline August & $0.055^{* * *}$ & 0.010 & $0.08^{* * *}$ & 0.011 & $0.069 * * *$ & 0.010 & 0.015 & 0.011 & $0.069^{* * *}$ & 0.015 & $0.068^{* * *}$ & 0.011 \\
\hline Setpember & $0.019^{* * *}$ & 0.007 & $0.032^{* * *}$ & 0.004 & $0.025^{* * *}$ & 0.005 & 0.005 & 0.009 & $0.035^{* * *}$ & 0.006 & $0.023^{* * *}$ & 0.006 \\
\hline October & $0.035^{* * *}$ & 0.006 & $0.038^{* * *}$ & 0.005 & $0.037^{* * *}$ & 0.005 & 0.011 & 0.009 & $0.042^{* * *}$ & 0.005 & $0.036^{* * *}$ & 0.005 \\
\hline November & 0.004 & 0.005 & $0.016^{* * *}$ & 0.004 & $0.01^{* * *}$ & 0.004 & 0.036 & 0.025 & $0.023^{* * *}$ & 0.005 & $0.008^{* *}$ & 0.004 \\
\hline \multicolumn{13}{|l|}{ Duration } \\
\hline 1 month & -0.002 & 0.005 & $0.014^{* * *}$ & 0.003 & 0.004 & 0.004 & $0.04^{* * *}$ & 0.003 & $0.02^{* * *}$ & 0.004 & 0.003 & 0.004 \\
\hline 2 months & $0.016^{* * *}$ & 0.006 & $0.036^{* * *}$ & 0.003 & $0.023^{* * *}$ & 0.004 & $0.075^{* * *}$ & 0.007 & $0.046^{* * *}$ & 0.007 & $0.022^{* * *}$ & 0.004 \\
\hline 3 months & $0.042^{* * *}$ & 0.007 & $0.064^{* * *}$ & 0.004 & $0.049^{* * *}$ & 0.005 & $0.092^{* * *}$ & 0.005 & $0.074^{* * *}$ & 0.007 & $0.048^{* * *}$ & 0.005 \\
\hline 4 months & $0.042^{* * *}$ & 0.006 & $0.062^{* * *}$ & 0.004 & $0.048^{* * *}$ & 0.005 & $0.086^{* * *}$ & 0.006 & $0.079^{* * *}$ & 0.006 & $0.046^{* * *}$ & 0.005 \\
\hline 5 months & $0.074^{* * *}$ & 0.008 & $0.064^{* * *}$ & 0.005 & $0.064^{* * *}$ & 0.006 & $0.106^{* * *}$ & 0.007 & $0.107^{* * *}$ & 0.011 & $0.061^{* * *}$ & 0.006 \\
\hline 6 months & $0.08^{* * *}$ & 0.007 & $0.1^{* * *}$ & 0.006 & $0.085^{* * *}$ & 0.006 & $0.117^{* * *}$ & 0.009 & $0.109^{* * *}$ & 0.006 & $0.086^{* * *}$ & 0.007 \\
\hline 7 months & $0.077^{* * *}$ & 0.006 & $0.085^{* * *}$ & 0.005 & $0.075^{* * *}$ & 0.005 & $0.125^{* * *}$ & 0.009 & $0.122^{* * *}$ & 0.006 & $0.073^{* * *}$ & 0.005 \\
\hline 8 months & $0.083^{* * *}$ & 0.008 & $0.098^{* * *}$ & 0.006 & $0.085^{* * *}$ & 0.006 & $0.176^{* * *}$ & 0.028 & $0.142^{* * *}$ & 0.008 & $0.082^{* * *}$ & 0.007 \\
\hline 9 months & $0.102^{* * *}$ & 0.009 & $0.109^{* * *}$ & 0.006 & $0.1^{* * *}$ & 0.007 & $0.149^{* * *}$ & 0.012 & $0.172^{* * *}$ & 0.012 & $0.094^{* * *}$ & 0.007 \\
\hline 10 months & $0.107^{* * *}$ & 0.008 & $0.13^{* * *}$ & 0.008 & $0.113^{* * *}$ & 0.007 & $0.166^{* * *}$ & 0.012 & $0.2^{* * *}$ & 0.014 & $0.106^{* * *}$ & 0.007 \\
\hline 11 months & $0.417^{* * *}$ & 0.017 & $0.388^{* * *}$ & 0.015 & $0.399^{* * *}$ & 0.015 & $0.254^{* * *}$ & 0.027 & $0.454^{* * *}$ & 0.028 & $0.398^{* * *}$ & 0.015 \\
\hline 12 months & $0.146^{* * *}$ & 0.014 & $0.145^{* * *}$ & 0.014 & $0.139^{* * *}$ & 0.013 & $0.166^{* * *}$ & 0.014 & $0.196^{* * *}$ & 0.015 & $0.138^{* * *}$ & 0.014 \\
\hline \multicolumn{13}{|c|}{$\begin{array}{l}\text { "State- } \\
\text { dependency" }\end{array}$} \\
\hline $\begin{array}{r}\text { Accumulated } \\
\text { inflation }\end{array}$ & $0.01^{* * *}$ & 0.002 & $0.005^{* * *}$ & 0.002 & $0.007^{* * *}$ & 0.002 & $0.007^{* *}$ & 0.003 & -0.001 & 0.002 & $0.009^{* * *}$ & 0.002 \\
\hline $\begin{array}{r}\text { Accumulated } \\
\text { unemployment }\end{array}$ & $-0.028^{* * *}$ & 0.004 & $-0.031^{* * *}$ & 0.003 & $-0.03^{* * *}$ & 0.003 & -0.008 & 0.007 & $-0.023^{* * *}$ & 0.003 & $-0.031^{* * *}$ & 0.003 \\
\hline $\begin{array}{r}\text { Accumulated } \\
\text { productivity }\end{array}$ & 0.000 & 0.000 & 0.000 & 0.000 & 0.000 & 0.000 & 0.000 & 0.000 & 0.000 & 0.000 & 0.000 & 0.000 \\
\hline \multicolumn{13}{|l|}{$\begin{array}{l}\text { Type } \\
\text { of relationship }\end{array}$} \\
\hline Partnership & $-0.01^{*}$ & 0.006 & -0.002 & 0.009 & -0.005 & 0.005 & -0.017 & 0.038 & 0.001 & 0.013 & -0.008 & 0.006 \\
\hline Single & -0.003 & 0.002 & 0.000 & 0.003 & -0.001 & 0.002 & -0.006 & 0.013 & 0.002 & 0.004 & -0.003 & 0.002 \\
\hline age & $-0.015^{* * *}$ & 0.002 & $-0.014^{* * *}$ & 0.001 & $-0.014^{* * *}$ & 0.001 & $-0.022^{* * *}$ & 0.003 & $-0.02^{* * *}$ & 0.002 & $-0.014^{* * *}$ & 0.002 \\
\hline \multicolumn{13}{|l|}{$\begin{array}{l}\text { Weekly } \\
\text { contract hours }\end{array}$} \\
\hline $12-<20$ & & & 0.001 & 0.002 & 0.001 & 0.002 & $0.008^{* *}$ & 0.004 & 0.003 & 0.002 & 0.001 & 0.003 \\
\hline $20-<25$ & & & $-0.005^{*}$ & 0.003 & $-0.006^{*}$ & 0.003 & 0.008 & 0.005 & 0.003 & 0.003 & $-0.006^{*}$ & 0.003 \\
\hline $25-<30$ & & & $-0.011^{* * *}$ & 0.004 & $-0.01^{* *}$ & 0.004 & 0.008 & 0.006 & -0.001 & 0.004 & $-0.011^{* *}$ & 0.004 \\
\hline $30-<35$ & $-0.015^{* *}$ & 0.007 & $-0.013^{* * *}$ & 0.004 & $-0.01^{* *}$ & 0.005 & $0.017^{* *}$ & 0.008 & 0.002 & 0.004 & $-0.011^{* *}$ & 0.006 \\
\hline 35 and more & $-0.054^{* * *}$ & 0.009 & $-0.045^{* * *}$ & 0.005 & $-0.036^{* * *}$ & 0.005 & 0.010 & 0.008 & $-0.024^{* * *}$ & 0.005 & $-0.037^{* * *}$ & 0.006 \\
\hline Business size & & & & & & & & & & & & \\
\hline 2 & -0.020 & 0.013 & $-0.079 *$ & 0.048 & $-0.045^{*}$ & 0.025 & $-0.115^{*}$ & 0.059 & $-0.119^{* * *}$ & 0.046 & $-0.025^{* *}$ & 0.012 \\
\hline 3 to 4 & $-0.025^{*}$ & 0.013 & -0.081 & 0.049 & $-0.048^{*}$ & 0.026 & $-0.117^{*}$ & 0.062 & $-0.124^{* * *}$ & 0.047 & $-0.025^{* *}$ & 0.012 \\
\hline 5 to 9 & $-0.03^{* *}$ & 0.013 & $-0.091^{*}$ & 0.051 & $-0.054^{* *}$ & 0.027 & $-0.141^{* *}$ & 0.064 & $-0.13^{* * *}$ & 0.049 & $-0.033^{* * *}$ & 0.012 \\
\hline 10 to 19 & $-0.029^{* *}$ & 0.013 & $-0.09 *$ & 0.053 & $-0.053^{*}$ & 0.028 & $-0.13^{*}$ & 0.068 & $-0.132^{* * *}$ & 0.051 & $-0.03^{* *}$ & 0.013 \\
\hline 20 to 49 & $-0.025^{*}$ & 0.014 & -0.092 & 0.058 & $-0.052^{*}$ & 0.030 & $-0.124^{*}$ & 0.075 & $-0.137^{* *}$ & 0.054 & $-0.026^{* *}$ & 0.013 \\
\hline 50 to 99 & -0.022 & 0.015 & -0.099 & 0.063 & -0.053 & 0.032 & -0.128 & 0.081 & $-0.156^{* * *}$ & 0.060 & $-0.023^{*}$ & 0.014 \\
\hline 100 to 149 & -0.015 & 0.016 & -0.096 & 0.068 & -0.047 & 0.034 & -0.126 & 0.083 & $-0.158^{* *}$ & 0.065 & -0.015 & 0.015 \\
\hline 150 to 199 & -0.013 & 0.017 & -0.085 & 0.072 & -0.040 & 0.036 & -0.089 & 0.092 & $-0.168^{* *}$ & 0.072 & -0.005 & 0.016 \\
\hline 200 to 249 & 0.003 & 0.018 & -0.085 & 0.075 & -0.035 & 0.038 & $-0.194^{*}$ & 0.100 & $-0.163^{* *}$ & 0.075 & 0.003 & 0.017 \\
\hline 250 to 499 & 0.015 & 0.017 & -0.066 & 0.079 & -0.017 & 0.040 & -0.125 & 0.106 & $-0.161^{*}$ & 0.088 & 0.023 & 0.016 \\
\hline 500 to 999 & $0.034^{* * *}$ & 0.012 & -0.061 & 0.084 & -0.005 & 0.043 & -0.176 & 0.130 & $-0.196^{*}$ & 0.108 & $0.038^{* * *}$ & 0.014 \\
\hline 1000 to 1999 & $0.058^{* * *}$ & 0.012 & -0.021 & 0.084 & 0.031 & 0.041 & -0.174 & 0.133 & -0.151 & 0.105 & $0.072^{* * *}$ & 0.016 \\
\hline 2000 or more & $0.073^{* * *}$ & 0.014 & 0.001 & 0.088 & 0.049 & 0.044 & -0.193 & 0.135 & -0.153 & 0.110 & $0.092^{* * *}$ & 0.024 \\
\hline Constant & $0.656^{* * *}$ & 0.069 & $0.649^{* * *}$ & 0.085 & $0.61^{* * *}$ & 0.066 & $0.944^{* * *}$ & 0.102 & $0.847^{* * *}$ & 0.067 & $0.61^{* * *}$ & 0.066 \\
\hline Observations & 2,24 & 959 & 2,46 & ,030 & 4,57 & ,206 & 128 & 783 & 835 & 661 & 3,816 &, 496 \\
\hline
\end{tabular}

Standard errors clustered at business unit level. ${ }^{* * *}$ Significant at the 1 percent level, ${ }^{* *}$ Significant at the 5 percent level, * Significant at the 10 percent level. 
Table 14: Wage rigidity by employee characteristics

\begin{tabular}{lccccc}
\hline \multicolumn{2}{l}{ Type of relationship } & & & & \\
Marriage & $3.0[2.7 ; 3.2]$ & $85.8[85.2 ; 86.3]$ & $11.3[10.8 ; 11.7]$ & -8.5 & 4.2 \\
Partnership & $3.0[2.7 ; 3.3]$ & $85.1[84.5 ; 85.6]$ & $11.9[11.4 ; 12.4]$ & -8.5 & 4.1 \\
Single & $3.4[3.1 ; 3.7]$ & $84.0[83.4 ; 84.5]$ & $12.6[12.2 ; 13.0]$ & -9.4 & 5.5 \\
& & & & & \\
Gender & & & & & \\
Male & $3.2[2.9 ; 3.6]$ & $85.3[84.6 ; 85.9]$ & $11.5[11.0 ; 12.0]$ & -8.6 & 4.7 \\
Female & $3.1[2.9 ; 3.4]$ & $84.6[84.1 ; 85.1]$ & $12.2[11.9 ; 12.6]$ & -9.2 & 4.9
\end{tabular}

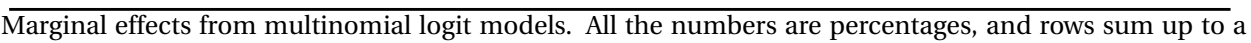
$100 \%$. Confidence intervals in brackets. The last two columns represents the percentage change in nominal wage, conditional on a wage decrease or increase. The total number of observations is 13,174,294.

Table 15: Distribution of contracts based on wage trajectory

\begin{tabular}{|c|c|c|c|c|c|c|c|c|c|c|c|c|}
\hline & \multirow{2}{*}{$\begin{array}{c}\text { Director } \\
\text { NA }\end{array}$} & \multicolumn{2}{|c|}{ Intern } & \multicolumn{2}{|c|}{ SWS-er } & \multicolumn{2}{|c|}{ Temp. workers } & \multicolumn{2}{|c|}{ On-call } & \multicolumn{2}{|c|}{ Rest } & \multirow{2}{*}{ Total } \\
\hline & & $\mathbf{T}$ & $\mathbf{U}$ & $\mathbf{T}$ & $\mathbf{U}$ & $\mathbf{T}$ & $\mathbf{U}$ & $\mathbf{T}$ & $\mathbf{U}$ & $\mathbf{T}$ & $\mathbf{U}$ & \\
\hline \multicolumn{13}{|l|}{ Full-time } \\
\hline Fixed hours & 1.2 & 0.2 & 0.1 & 0.1 & 0.3 & & & & & 16.0 & 36.7 & 54.5 \\
\hline Flexible hours & & & & & & 0.9 & 0.2 & 0.6 & 0.5 & & & 2.2 \\
\hline \multicolumn{13}{|l|}{ Part-time } \\
\hline Fixed hours & 0.3 & 0.1 & 0.0 & 0.1 & 0.2 & & & & & 13.9 & 23.5 & 38.0 \\
\hline Flexible hours & & & & & & 0.5 & 0.1 & 2.6 & 2.2 & & & 5.3 \\
\hline \multirow{2}{*}{ Total } & \multirow{2}{*}{1.5} & 0.2 & 0.1 & 0.1 & 0.4 & 1.4 & 0.2 & 3.2 & 2.7 & 29.9 & 60.2 & \\
\hline & & \multicolumn{2}{|c|}{0.4} & \multicolumn{2}{|c|}{0.6} & \multicolumn{2}{|c|}{1.6} & \multicolumn{2}{|c|}{5.9} & \multicolumn{2}{|c|}{90.1} & \\
\hline \multirow{2}{*}{$\begin{array}{c}\text { \% working } \\
\text { overtime }\end{array}$} & \multirow{2}{*}{0.3} & \multirow{2}{*}{\multicolumn{2}{|c|}{$\begin{array}{c}0.0 \\
0.9\end{array}$}} & & 0.1 & 12.2 & 7.6 & & 1.8 & 3.0 & 6.2 & 48 \\
\hline & & & & \multicolumn{2}{|c|}{0.1} & \multicolumn{2}{|c|}{11.6} & \multicolumn{2}{|c|}{1.7} & \multicolumn{2}{|c|}{5.0} & 4.8 \\
\hline
\end{tabular}

T: Tenured, U: Untenured, NA: Not aplicable. The total number of wage trajectories is 567,130 . All the num bers are percentages.

Table 16: Distribution of contracts based on observations

\begin{tabular}{|c|c|c|c|c|c|c|c|c|c|c|c|c|}
\hline & \multirow{2}{*}{$\begin{array}{c}\text { Director } \\
\text { NA }\end{array}$} & \multicolumn{2}{|c|}{ Intern } & \multicolumn{2}{|c|}{ SWS-er } & \multicolumn{2}{|c|}{ Temp. workers } & \multicolumn{2}{|c|}{ On-call } & \multicolumn{2}{|c|}{ Rest } & \multirow{2}{*}{ Total } \\
\hline & & $\mathbf{T}$ & $\mathbf{U}$ & $\mathbf{T}$ & $\mathbf{U}$ & $\mathbf{T}$ & $\mathbf{U}$ & $\mathbf{T}$ & $\mathbf{U}$ & $\mathbf{T}$ & $\mathbf{U}$ & \\
\hline \multicolumn{13}{|l|}{ Full-time } \\
\hline Fixed hours & 1.2 & 0.0 & 0.0 & 0.0 & 0.7 & & & & & 8.9 & 36.5 & 47.4 \\
\hline Flexible hours & & & & & & 0.2 & 0.1 & 0.1 & 0.1 & & & 0.5 \\
\hline \multicolumn{13}{|l|}{ Part-time } \\
\hline Fixed hours & 0.4 & 0.0 & 0.0 & 0.1 & 0.4 & & & & & 10.7 & 37.4 & 49.0 \\
\hline Flexible hours & & & & & & 0.3 & 0.0 & 1.3 & 1.5 & & & 3.1 \\
\hline \multirow{2}{*}{ Total } & \multirow{2}{*}{1.6} & 0.1 & 0.0 & 0.2 & 1.1 & 0.5 & 0.1 & 1.4 & 1.6 & 19.6 & 73.9 & \\
\hline & & \multicolumn{2}{|c|}{0.1} & \multicolumn{2}{|c|}{1.3} & \multicolumn{2}{|c|}{0.6} & \multicolumn{2}{|c|}{3.0} & \multicolumn{2}{|c|}{93.5} & \\
\hline \multirow{2}{*}{$\begin{array}{c}\text { \% working } \\
\text { overtime }\end{array}$} & \multirow{2}{*}{0.4} & 2.3 & 2.9 & 0.0 & 0.0 & 14.1 & 12.3 & & 2.4 & 5.7 & 7.7 & 69 \\
\hline & & \multicolumn{2}{|c|}{2.6} & \multicolumn{2}{|c|}{0.0} & \multicolumn{2}{|c|}{13.8} & \multicolumn{2}{|c|}{2.2} & \multicolumn{2}{|c|}{7.3} & \\
\hline
\end{tabular}

T: Tenured, U: Untenured, NA: Not aplicable. The total number of observations is $13,174,294$. All the num bers are percentages. 
Table 17: Number of observations lost in each step of the data cleaning process (5\% sample)

\begin{tabular}{lcc} 
Step & \# of observations & \# observation lost \\
\hline $\begin{array}{l}\text { Raw data } \\
\text { Elimination of meaningless }\end{array}$ & $26,384,601$ & \\
values & $21,515,162$ & $4,869,439$ \\
$\begin{array}{l}\text { Elimination of percentiles 1\% } \\
\text { and 99\% }\end{array}$ & $21,327,537$ & 187,625 \\
$\begin{array}{l}\text { Possible elimination of the first } \\
\text { and last observation per wage } \\
\text { trajectory }\end{array}$ & $20,623,277$ & 704,260 \\
$\begin{array}{l}\text { Elimination of wage } \\
\text { trajectories of less than 3 }\end{array}$ & $20,190,719$ & \\
$\begin{array}{l}\text { months } \\
\begin{array}{l}\text { Elimination of excessively } \\
\text { volatile wage trajectories }\end{array}\end{array}$ & $14,905,628$ & \\
$\begin{array}{l}\text { Correction of wage trajectories } \\
\text { with a "V” or inverted-"V” } \\
\text { shape }\end{array}$ & $14,905,628$ & $5,285,091$ \\
$\begin{array}{l}\text { Correction of spurious wage } \\
\text { reversals }\end{array}$ & $14,905,628$ & 0 \\
\hline
\end{tabular}

Table 18: Sector

\begin{tabular}{lccccc}
\hline & \multicolumn{3}{c}{ Frequency } & \multicolumn{2}{c}{ Average size } \\
& Decrease & No change & Increase & Decrease & Increase \\
\hline Private companies & $4.1[3.9 ; 4.3]$ & $84.4[84.0 ; 84.8]$ & $11.5[11.0 ; 12.0]$ & -9.0 & 5.5 \\
Subsidized sector & $2.7[2.2 ; 3.2]$ & $83.7[82.7 ; 84.7]$ & $13.6[12.9 ; 14.3]$ & -8.7 & 4.1 \\
Education & $1.8[1.5 ; 2.1]$ & $87.1[86.3 ; 88.0]$ & $11.1[10.5 ; 11.6]$ & -12.5 & 5.4 \\
Municipalities & $1.1[0.9 ; 1.4]$ & $87.6[87.2 ; 88.0]$ & $11.3[11.0 ; 11.6]$ & -4.7 & 2.4 \\
\hline
\end{tabular}

Marginal effects from multinomial logit models. All the numbers are percentages, and rows sum up to a $100 \%$. Confidence intervals in brackets. The last two columns represents the percentage change in nominal wage, conditional on a wage decrease or increase. The total number of observations is 13,174,294. 


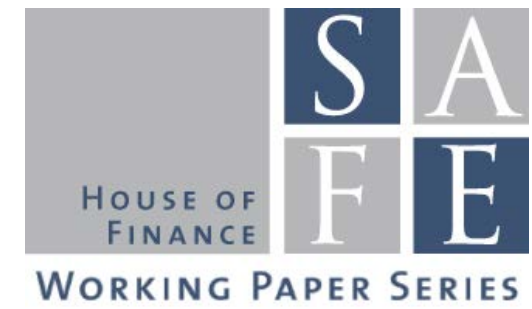

\section{Recent Issues}

No. 257 Baptiste Massenot, Giang Nghiem

No. 256 Christian Schlag, Kailin Zeng

No. 255 Silvia Dalla Fontana, Marco Holz auf der Heide, Loriana Pelizzon, Martin Scheicher

No. 254 Martin R. Goetz

No. 253 Thomas Johann, Talis Putnins, Satchit Sagade, Christian Westheide

No. 252 Nicole Branger, Patrick Konermann, Christian Schlag

No. 251 Wenhui Li, Christian Wilde

No. 250 Nathanael Vellekoop, Mirko Wiederholt

No. 249 Yuri Pettinicchi, Nathanael Vellekoop

No. 248 Jasmin Gider, Simon N. M. Schmickler, Christian Westheide

No. 247 Mario Bellia, Loriana Pelizzon, Marti G. Subrahmanyam, Jun Uno, Draya Yuferova

No. 246 Reint Gropp, Felix Noth, Ulrich Schüwer

No. 245 Charline Uhr, Steffen Meyer, Andreas Hackethal

No. 244 Mauro Bernardi, Michele Costola
Depressed Demand and Supply

Horizontal Industry Relationships and Return Predictability

The Anatomy of the Euro Area Interest Rate Swap Market

Financing Conditions and Toxic Emissions

Quasi-Dark Trading: The Effects of Banning Dark Pools in a World of Many Alternatives

Optimists and Pessimists in (In)Complete Markets

Belief Formation and Belief Updating under Ambiguity: Evidence from Experiments

Inflation Expectations and Choices of Households

Job Loss Expectations, Durable Consumption and Household Finances: Evidence from Linked Survey Data

High-Frequency Trading and Price Informativeness

Paying for Market Liquidity: Competition and Incentives

What Drives Banks' Geographic Expansion? The Role of Locally Non-Diversifiable Risk

Smoking Hot Portfolios? Self-Control and Investor Decisions

High-Dimensional Sparse Financial Networks through a Regularised Regression Model 